\title{
Dissecting the genetic overlap of education, socioeconomic status, and mental health
}

\author{
F. R. Wendt, ${ }^{1,2}$ G. A. Pathak ${ }^{1,2}$, T. Lencz, ${ }^{3}$ J. H. Krystal, ${ }^{1}$ J. Gelernter, ${ }^{1,2,4}$ \\ R. Polimanti ${ }^{1,2, *}$
}

1. Department of Psychiatry, Yale School of Medicine, New Haven, CT 06511, USA

2. VA CT Healthcare Center, West Haven, CT 06516, USA

3. Division of Psychiatry Research, The Zucker Hillside Hospital, Glen Oaks, NY 11004, USA; Department of Psychiatry, Zucker School of Medicine at Hofstra/Northwell, Hempstead, NY 11549, USA; Institute for Behavioral Science, Feinstein Institute for Medical Research, Manhasset, NY 11030, USA

4. Departments of Genetics and Neuroscience, Yale University School of Medicine, New Haven, CT 06510, USA

* Corresponding author

Short Title: Uncovering the unique genetics of mental health

\begin{abstract}
Socioeconomic status (SES) and education (EDU) are phenotypically associated with psychiatric disorders and behavior. It remains unclear how these associations influence the genetic risk for mental health traits and EDU/SES individually. Using information from $>1$ million individuals, we conditioned the genetic risk for psychiatric disorders, personality traits, brain imaging phenotypes, and externalizing behaviors with genome-wide data for EDU/SES. Accounting for EDU/SES significantly affected the observed heritability of psychiatric traits ranging from $2.44 \% \mathrm{~h}^{2}$ decrease for bipolar disorder to $29.0 \% \mathrm{~h}^{2}$ decrease for Tourette syndrome. Neuroticism $\mathrm{h}^{2}$ significantly increased by $20.23 \%$ after conditioning with SES. After EDU/SES conditioning, novel neuronal cell-types were identified for risky behavior (excitatory), major depression (inhibitory), schizophrenia (excitatory and GABAergic), and bipolar disorder (excitatory). Conditioning with EDU/SES also revealed unidirectional causality between brain morphology and mental health phenotypes. Our results indicate genetic discoveries of mental health outcomes may be limited by genetic overlap with EDU/SES.
\end{abstract}


medRxiv preprint doi: https://doi.org/10.1101/2020.01.09.20017079; this version posted January 13, 2020. The copyright holder for this preprint (which was not certified by peer review) is the author/funder, who has granted medRxiv a license to display the preprint in perpetuity.

All rights reserved. No reuse allowed without permission.

\section{Introduction}

Education (EDU) and socioeconomic status (SES) are risk or protective factors for traits related to mental health and disease $(1,2)$. Social position has been repeatedly correlated with mood, anxiety, and substance use related disorders, while EDU phenotypes such as educational attainment, math ability, and fluid intelligence are overall protective factors for development of neurological and psychiatric conditions (2). They are epidemiologically correlated, but the specific EDU and/or SES phenotypes used in epidemiological studies clearly account in part for observed differences between groups (3). It is therefore imperative to understand how EDU and SES phenotypes influence what we understand about human health and disease.

Genome-wide association studies (GWAS) are powerful hypothesis-free genetic studies for detecting risk loci (e.g., single nucleotide polymorphisms (SNPs) or genes) for phenotypes of interest. Their widespread use has led to risk locus discovery underlying thousands of phenotypes across the spectrum of human health and disease, including mental and physical health and disease, personality, anthropometric measures, intelligence, and behavior (4). An observation generated from large-scale GWAS is the widespread presence of pleiotropy; a single SNP (or a set of SNPs) may have a range of relatively small effects on multiple similar or disparate phenotypes. On a genome-wide scale, these pleiotropic effects, detected using GWAS summary data, may be used to determine genetic correlations between phenotypes to putatively identify genetic underpinnings of trait pairs (5).

The EDU phenotypes educational attainment and cognitive performance have relatively high SNP-heritability: the phenotypic variance explained by genetic information was 40-60\% (6) and $21.5 \%$ (7), respectively. Socioeconomic status (SES) is defined as the social standing or class of an individual or group, often measured as a combination of education, income, and occupation (8). SES phenotypes such as household income and Townsend deprivation index (i.e., measure of SES based on whether individuals own their homes, their employment status, their access to a vehicle, and whether or not individuals share living accommodations with others) are significantly heritable and show strong genetic correlation with EDU traits (9). Additionally there is pleiotropy of genetic risks between EDU/SES and a range of mental health outcomes (e.g., psychiatric disorders, personality traits, internalizing and externalizing behaviors, social science outcomes, and brain imaging phenotypes) $(10,11)$.

The epidemiological observations of high genetic correlations between genetic risk for EDU/SES and mental health outcomes $(1,2)$ raise two critical questions: (1) how might the strong genetic effects of EDU/SES affect our understanding of the overall genetic risk for mental health outcomes? and (2) is there evidence that genetic effects of mental health and disease phenotypes affect our understanding of the overall genetic risk for EDU/SES? The goal of this study was to investigate how the shared genetic effects between the general categories of EDU, SES, and mental health outcome phenotypes influence genetic risk for individual phenotypes within each of these classes.

There are several ways to approach these questions. First, polygenic risk scoring (PRS) (12) is a tempting approach; but PRS using mental health/disease to predict the same or different phenotypes from an independent dataset often explain very little variance in the outcome phenotype (13-15). PRS also cannot detect specific biology underlying each phenotype. Second is multi-trait analysis of GWAS (MTAG), which jointly analyses GWAS summary statistics and adjusts per-SNP effect estimates and association p-values using the strength of the genetic correlation between phenotypes (16). Genetic correlations between EDU/SES and related phenotypes have, however, demonstrable biases from environmental confounders. If genetic 
medRxiv preprint doi: https://doi.org/10.1101/2020.01.09.20017079; this version posted January 13, 2020. The copyright holder for this preprint (which was not certified by peer review) is the author/funder, who has granted medRxiv a license to display the preprint in perpetuity.

All rights reserved. No reuse allowed without permission.

correlations involving EDU and SES proxy phenotypes are significantly upwardly biased, an MTAG adjustment of summary statistics may inappropriately correct (i.e., bias) the summary statistics used for this study. To disentangle the complex genetic overlaps between EDU/SES and mental health, we therefore used multi-trait conditioning and joint analysis (mtCOJO), which generates conditioned GWAS summary statistics for each phenotype of interest after correcting for the per-SNP effects of another phenotype (17). The mtCOJO approach is not based on genetic correlation; it is based on the causal relationship between trait pairs inferred by Mendelian randomization (MR). For our phenotypes of interest mtCOJO is an advantageous approach, which, in theory, is independent of the effects of environmental confounders. MR detects causal inferences between trait pairs using non-modifiable risk factors (SNPs) associated with an exposure variable and only associated with an outcome variable through the exposure. Because SNPs are non-modifiable, environmental confounders of the relationship between SNP, exposure, and outcome should not influence MR estimates.

We used the mtCOJO approach to condition mental health outcomes with the per-SNP effects of EDU and SES phenotypes and investigate their underlying biology at multiple levels: (1) risk locus detection, (2) heritability $\left(\mathrm{h}^{2}\right)$, (3) gene-set enrichment, (4) tissue transcriptomic profile enrichment, (5) cell type transcriptomic profile enrichment, (6) phenotype relationships via structural equation modeling and genetic correlation, and (7) latent genetically causal relationships (see flow diagram Fig S1). Our findings identify several cell types and phenotype relationships that were masked by the shared genetic etiology between mental health outcomes and EDU/SES. Furthermore, we demonstrate that the same multi-level analyses of EDU and SES are largely robust to the effects of shared genetic etiology with mental health outcomes. 


\section{Results}

\section{Trait Inclusion}

The genetic correlations $\left(\mathrm{r}_{\mathrm{g}}\right)$ between EDU (educational attainment, cognitive performance, highest math class, and self-rated math ability), SES (household income and Townsend deprivation index), and mental health outcomes (i.e., psychiatric disorders, personality traits, externalizing behaviors, social science outcomes, and brain imaging phenotypes) were detected using the Linkage Disequilibrium Score Regression (LDSC) method (Fig. 1, Table S1, Figs. S2 \& S3) (18). Genetic correlations for EDU and SES phenotype categories were analyzed independently to identify brain imaging phenotypes nominally genetically correlated with at least two of the four EDU phenotypes and both SES phenotypes. We detected only two traits genetically correlated with at least two of the four EDU phenotypes: left insular cortex (mean $\mathrm{r}_{\mathrm{g}}=-0.122$, se $=0.013$ ) and left subcallosal cortex (mean $r_{g}=-0.106$, se $=0.009$ ). These two brain imaging phenotypes were included in EDU conditioning experiments.

Twenty-nine brain imaging phenotypes were genetically correlated with both SES phenotypes. We tested genetic correlation between these 29 brain imaging phenotypes to identify a subset of high heritability traits to include in SES conditioning experiments. We identified six such brain imaging phenotypes (Fig. S2). These are: cortex volume, left hemisphere medialorbitofrontal area, right insular cortex, right temporal fusiform cortex, subcortical gray matter volume, and volume of right-ventral diencephalon. The SES phenotypes income and deprivation index are inversely genetically correlated as visible in Fig. 1.

\section{Conditioning Heritability and Risk Locus Discovery}

We tested the effects of conditioning on observed-scale heritability $\left(\mathrm{h}^{2}\right)$ using LDSC (18). Psychiatric disorders were most sensitive to shared genetic etiology with EDU/SES phenotypes. Except for major depressive disorder (MDD), anxiety, and posttraumatic stress disorder (PTSD), conditioning reduced the $\mathrm{h}^{2}$ for all psychiatric disorders relative to their original estimates $\left(\mathrm{h}^{2}\right.$ decrease ranged from $2.44 \% \pm 0.187$ for bipolar disorder (original $\mathrm{h}^{2}=4.39 \%$; highest conditioned $\mathrm{h}^{2}=2.22 \%, \mathrm{se}=0.460, \mathrm{p}=5.67 \times 10^{-65}$; lowest conditioned $\mathrm{h}^{2}=1.70 \%$, se $=0.440, \mathrm{p}=4.05 \times 10^{-}$ ${ }^{80}$ ) to $29.0 \% \pm 0.105$ for Tourette syndrome (original $\mathrm{h}^{2}=35.6 \%$; highest conditioned $\mathrm{h}^{2}=6.72 \%$, $\mathrm{se}=0.770, \mathrm{p}=2.61 \times 10^{-18}$; lowest conditioned $\mathrm{h}^{2}=6.43 \%$, se $\left.=0.730, \mathrm{p}=1.27 \times 10^{-18}\right)$; Fig. $\left.2 \mathrm{~A}\right)$. Tourette syndrome exhibited the largest decrease in $\mathrm{h}^{2}$ after conditioning with the effects of EDU/SES phenotypes (Tourette syndrome mean $\mathrm{p}_{\text {diff }}$ compared to original $\mathrm{h}^{2}=2.24 \times 10^{-11}$, se $=$ $4.42 \times 10^{-12}$ ). Conversely, two phenotypes exhibited significant increases in $\mathrm{h}^{2}$ after conditioning with EDU/SES phenotypes: neuroticism (highest conditioned $\mathrm{h}^{2}=20.2 \%$, se $=0.630, \mathrm{p}=3.08 \times 10^{-}$ 226. lowest conditioned $\mathrm{h}^{2}=18.1 \%$, se $=0.590, \mathrm{p}=2.35 \times 10^{-207}$ ) and subjective well-being (highest conditioned $\mathrm{h}^{2}=3.65 \%$, se $=0.220, \mathrm{p}=8.11 \times 10^{-62}$; lowest conditioned $\mathrm{h}^{2}=3.34 \%$, $\mathrm{se}=0.220, \mathrm{p}$ $=4.67 \times 10^{-52}$ ).

Conditioning the neuroticism GWAS (original $\mathrm{h}^{2}=9.41 \%$ ) with EDU/SES phenotypes revealed several novel, confirmed known LD-independent risk loci, and increased heritability (range $=59$ loci (neuroticism conditioned with income) to 100 loci (neuroticism conditioned with deprivation index; Fig. 2B). We observed an increase in the association signal in the neuroticism GWAS with the strongest effects observed after conditioning with SES phenotypes income (lambda $\mathrm{GC}=1.36$; intercept $=0.971$, se $=0.009$ ) and deprivation index (lambda $\mathrm{GC}=1.75$; intercept $=0.967$, se $=0.009$; Fig. 2C). This increase was not related to an increase in the potential bias of population stratification (there was no significant change in the LDSC intercept, $p>0.05$ ), supporting that the observation was attributable to the increased detection of valid neuroticism 
polygenic signals. Using a physical proximity single-SNP-single-gene based annotation of conditioned neuroticism genomic risk loci, the top gene sets included Gene Ontology (GO) biological process synaptic signaling (enrichment FDR $=1.5 \times 10^{-4}$ ), GO cellular component synapse part (enrichment FDR $=5.40 \times 10^{-4}$ ), and Kyoto Encyclopedia of Genes and Genomes (KEGG) dopaminergic synapses (enrichment FDR = 0.046).

The significant increase in $\mathrm{h}^{2}$ for GWAS of subjective well-being (original $\mathrm{h}^{2}=2.50 \%$ ) uncovered a $5.7 \mathrm{~kb}$ genomic risk locus on chromosome 7 (minimum genome-wide significant $\mathrm{p}$ value $=1.45 \times 10^{-8}$ ) which maps to the $\alpha_{2} \delta_{1}$ subunit of calcium voltage-gated channel (CACNA2D1). The protein encoded by $C A C N A 2 D 1$ has been implicated in familial epilepsy and intellectual disability pedigrees but to our knowledge has not been implicated in genome-wide studies of these phenotypes $(19,20)$.

\section{Tissue-Type Transcriptomic Profile Enrichment Differences}

After conditioning with GWAS of EDU/SES phenotypes, schizophrenia was the only mental health outcome demonstrating significant changes in tissue transcriptomic profile enrichment. Compared to original schizophrenia brain tissue transcriptomic profile enrichments, all conditioned schizophrenia brain tissue GTEx annotations, with the exception of c1 cervical spinal cord, had significantly decreased enrichments (Fig. S4). The maximum decrease was observed after conditioning schizophrenia with the EDU phenotype educational attainment (average beta decrease for all brain tissue annotations $=0.038 \pm 0.004$ ). After conditioning with EDU and SES phenotypes, the cerebellum and cerebellar hemisphere GTEx annotations remained the most enriched in the schizophrenia GWAS (original cerebellum enrichment $=0.080, \mathrm{p}=$ $1.76 \times 10^{-22}$; original cerebellar hemisphere enrichment $=0.077, \mathrm{p}=1.28 \times 10^{-22}$; mean conditioned cerebellum enrichment $=0.047 \pm 0.001$, FDR $<0.05$; mean conditioned cerebellar hemisphere enrichment $=0.047 \pm 0.001$, FDR $<0.05$ ). After adjusting for the effects of cognitive performance and educational attainment and correcting for multiple testing, we uncovered enrichment of skeletal muscle tissue transcriptomic profiles in the schizophrenia GWAS (original skeletal muscle enrichment $=0.009, \mathrm{p}=0.135$; skeletal muscle enrichment conditioned with educational attainment $=0.010, \mathrm{p}=0.032$; skeletal muscle enrichment conditioned with cognitive performance $=0.011, \mathrm{p}=0.024)(21)$.

\section{Cell-Type Transcriptomic Profile Discoveries}

Cell-type transcriptomic profile enrichments were evaluated in two ways: (1) assess differences in within-data-set cell-type enrichments before and after conditioning with EDU/SES (based on MAGMA cell-type enrichment Step 1 (22)) and (2) assess the effects of conditioning on the detection of conditionally independent proportionally significant (PS) cell type enrichments (based on MAGMA cell-type enrichment Step 3 (22)). PS cell-types are those whose genetic signals could be differentiated from one another. PS values $\geq 0.80$ indicate independent genetic signals relative to a second cell type. We then used genes whose expression profiles define the excitatory (Ex) and inhibitory (In) cell types of PsychENCODE (23) to perform gene set enrichment analyses of GO and KEGG gene sets.

There were no differences in cell-type transcriptomic profile enrichments for mental health outcomes (MAGMA cell-type Step 1) after conditioning with EDU/SES; however, we discovered several PS cell-type pairs not detected in the unconditioned GWAS for (1) risky behavior, (2) $M D D$, and (3) schizophrenia (MAGMA cell-type Step 3). These PS cell-type findings and relevant gene set results for are described in detail below. 
In unconditioned GWAS of risky behavior, there were no PS cell-type enrichments After conditioning with the EDU phenotypes cognitive performance and educational attainment, human cortex fetal quiescent and Ex2 were conditionally independent from one another (risky behavior conditioned with cognitive performance $\operatorname{Ex} 2 \beta=0.035, \mathrm{p}=7.48 \times 10^{-4}$, PS $=1.37$; fetal quiescent $\beta=0.023, \mathrm{p}=0.032$, PS $=1.82$; risky behavior conditioned with educational attainment $\mathrm{Ex} 2 \beta=$ $0.034, \mathrm{p}=0.001$, PS $=1.38$; fetal quiescent $\beta=0.024, \mathrm{p}=0.030, \mathrm{PS}=1.77$; Fig 3A). Ex2 neurons also were detected in the risk tolerance GWAS after conditioning with educational attainment, but this signal could not be distinguished from hippocampal CA1 subfield cells. The genes that define the Ex 2 cell type were enriched in nervous system development (GO:0007399; enrichment FDR $\left.=3.70 \times 10^{-4}\right)$ and eye development $\left(\mathrm{GO}: 001654\right.$; enrichment FDR $\left.=6.30 \times 10^{-4}\right)$ gene sets.

The unconditioned $M D D$ GWAS exhibited cell-type transcriptomic profile enrichments between adult GABAergic neurons, In6b, and gestational week 10 (GW10) stem cells. After conditioning with self-rated math ability, the genetic signal from human midbrain neurons was conditionally independent from lateral geniculate nucleus (LGN) GABAergic neurons ( $\beta$ relative to midbrain neurons $=0.041, \mathrm{p}=0.002$, PS $=0.822$; Fig 3B), In6b neurons ( $\beta$ relative to midbrain neurons $\left.=0.517, \mathrm{p}=6.59 \times 10^{-6}, \mathrm{PS}=0.969\right)$, and In5 neurons $(\beta$ relative to midbrain neurons $=$ $\left.0.039, \mathrm{p}=5.26 \times 10^{-5}, \mathrm{PS}=0.813\right)$. The gene expression profiles of these cell types implicate the neurotransmitter transport (GO:0007269; enrichment FDR $=0.003$ ) and locomotory behavior (GO:0007626; enrichment FDR = 0.015) gene sets in MDD psychopathology.

The cell-type transcriptomic profiles underlying schizophrenia initially highlighted the role of Ex7 and human cortical neurons with conditionally independent genetic signals. After conditioning the schizophrenia GWAS with self-rated math ability, we uncovered conditionally independent PS genetic signals from GW26 GABAergic neurons and GW10 stem cells (GABAergic neuron $\beta=0.046, p=9.46 \times 10^{-9}$, PS $=1.00$; GW10 stem cell $\beta=0.031, p=1.04 \times 10^{-}$ ${ }^{4}$, PS = 1.00; Fig 3C and 3D). Importantly, the independent genetic signals of Ex7 and human cortical neurons persisted after conditioning the schizophrenia GWAS with EDU and SES phenotypes. There were no conditionally independent PS cell-type signals in the unconditioned GWAS, but the GWAS of bipolar disorder conditioned with educational attainment revealed PS genetic signals from (1) Ex7 ( $\beta$ relative to GABAergic neurons from the lateral geniculate nucleus $(\mathrm{LGN})=0.043, \mathrm{p}=1.50 \times 10^{-10}, \mathrm{PS}=0.952$ and $\mathrm{Ex} 7$ beta relative to $\mathrm{LGN}$ human cortical neurons $\left.=0.035, \mathrm{p}=5.46 \times 10^{-6}, \mathrm{PS}=0.999\right),(2)$ LGN GABAergic neurons $(\beta$ relative to Ex7 $=0.045, \mathrm{p}=$ $\left.1.42 \times 10^{-4}, \mathrm{PS}=0.871\right)$, and $(3)$ human cortical neurons $(\beta$ relative to $\operatorname{Ex} 7=0.001, \mathrm{p}=0.044$, PS $=0.904$ ) but could not distinguish genetic signals between the LGN GABAergic and human cortical neuron cell types. The genes contributing to the Ex7 cell type were enriched in gene sets related to nervous system processes (GO:0050877; enrichment FDR $=0.014)$ and synaptic signaling (GO:0099536; enrichment FDR = 0.023).

\section{Correlative, Latent, and Causal Relationships between Mental Health Outcomes}

Genetic correlations were assessed between all mental health outcomes after conditioning with each EDU and SES phenotype. Though small changes in genetic correlation magnitude were observed, the mental health outcome genetic correlations largely persisted even after conditioning with EDU/SES (Fig. S5). Two mental health outcomes, however, demonstrated significant changes in their genetic correlations after conditioning: (1) genetic correlations with neuroticism and (2) genetic correlations with volume of the right-ventral diencephalon. The genetic correlations between conditioned neuroticism and (1) $M D D$ (original $\mathrm{r}_{\mathrm{g}}=0.732$, mean conditioned $r_{g}=0.574 \pm 0.008$ ), (2) subjective well-being (original $r_{g}=-0.718$, mean conditioned $r_{g}=-0.522 \pm$ 
0.009), and (3) tiredness (unconditioned $r_{g}=0.638$, mean conditioned $r_{g}=0.490 \pm 0.017$ ) were at least nominally significant, and were in each case significantly lower than the unconditioned relationship. Unconditioned right-ventral diencephalon volume was significantly genetically correlated with subcortical gray matter volume (unconditioned $r_{g}=0.620, p=8.77 \times 10^{-15}$ ) and schizophrenia (unconditioned $\mathrm{r}_{\mathrm{g}}=0.134, \mathrm{p}=0.009$ ). After conditioning with income, the genetic correlation between volume of the right-ventral diencephalon and (1) subcortical gray matter volume persisted (conditioned $\mathrm{r}_{\mathrm{g}}=0.612, \mathrm{p}=1.44 \times 10^{-14}$ ), (2) schizophrenia switched directions and remained significant (conditioned $\mathrm{r}_{\mathrm{g}}=-0.120, \mathrm{p}=0.011, \mathrm{p}_{\mathrm{diff}}=2.72 \times 10^{-4}$ ), and (3) risk tolerance became significant (conditioned $\mathrm{r}_{\mathrm{g}}=-0.123, \mathrm{p}=0.044$ ). Conversely, after conditioning with the effects of deprivation index, the genetic correlation between volume of the right-ventral diencephalon and (1) subcortical gray matter volume was no longer significant (conditioned $r_{g}=$ -0.076, $\mathrm{p}=0.315$ ), (2) schizophrenia increased in magnitude (conditioned $\mathrm{r}_{\mathrm{g}}=0.198, \mathrm{p}=5.20 \times 10^{-}$ ${ }^{12}, \mathrm{p}_{\mathrm{diff}}=0.294$ ), and (3) several additional phenotypes become at least nominally significant (conditioned $\mathrm{r}_{\mathrm{g}}$ with autism spectrum disorder $(A S D)=0.478, \mathrm{p}=3.40 \times 10^{-30}$; with bipolar disorder $=0.181, \mathrm{p}=2.93 \times 10^{-8}$; with risky behavior $=0.418, \mathrm{p}=1.50 \times 10^{-59}$; with subjective wellbeing $=-0.363, \mathrm{p}=1.83 \times 10^{-17}$; and with tiredness $=0.343, \mathrm{p}=1.82 \times 10^{-20}$; Fig. S5).

Genomic Structural Equation Modeling (GenomicSEM) was used to identify how unconditioned and conditioned mental health outcomes relate to a latent unobserved genetic factor connecting them (Fig. 4). In unconditioned models, exploratory factor analysis (EFA) identified a two-factor model as best suited to explain the relationships among mental health outcomes. In confirmatory factor analysis (CFA), these two latent factors generally highlight relationships between all psychiatric disorders and brain imaging phenotypes (F1) and anxiety, MDD, depressive symptoms, and neuroticism $(\mathrm{F} 2)$. The correlation between unconditioned F1 and F2 was 0.14. After conditioning with highest math class, self-rated math ability, and deprivation index, the GWAS of neuroticism and MDD were no longer major contributors to the same factor. Conditioned F1 had major contributions from $M D D$ (mean loading $=0.611 \pm 0.005$ ) and depressive symptoms (loading $=0.538 \pm 0.098$ ) while conditioned $\mathrm{F} 2$ had major contributions from neuroticism (loading $=0.877 \pm 0.080$ ) and anxiety (loading $=0.658 \pm 0.009$ ). Interestingly, after conditioning with the SES phenotype income, the SEM best-fit converged on a single common factor between all mental health outcomes with major contributions from $M D D$ (loading $=0.808$, $\mathrm{se}=0.068$ ) and depressive symptoms (loading $=0.831$, se $=0.022$ ).

Latent Causal Variable (LCV) analyses were used to detect causal relationships between trait pairs that are independent of the genetic correlations between them (24). Considering only the unconditioned mental health outcomes, one trait pair exhibited significant genetic causality proportion (gĉp): left subcallosal cortex $\rightarrow$ obsessive compulsive disorder $\mathrm{gc \hat {p }}=0.167, \mathrm{p}=4.54 \times 10^{-}$ ${ }^{6}$ (Table 1 and Fig. 5). This partial causal relationship did not survive conditioning; however, thirteen unique trait pairs demonstrated significant gĉp after conditioning both traits with an EDU or SES phenotype (Table 1). Most notable were those causal relationships involving brain imaging phenotypes which became significant after conditioning with EDU phenotypes: (1) extraversion $\rightarrow$ left subcallosal corte $\left(\right.$ mean gêp $=0.188 \pm 0.107,1.23 \times 10^{-13}<\mathrm{p}$-values $<1.83 \times 10^{-6}$ ) after conditioning with educational attainment, highest math class, and self-rated math ability, (2) left subcallosal cortex $\rightarrow$ subjective well-being (mean gĉp $=0.745 \pm 0.009,1.45 \times 10^{-9}<\mathrm{p}$ values $<1.16 \times 10^{-8}$ ) after conditioning with cognitive performance, educational attainment, and highest math class, (3) openness $\rightarrow$ left insular cortex (mean gĉp $=0.296 \pm 0.050,2.54 \times 10^{-23}<\mathrm{p}$ values $<3.63 \times 10^{-8}$ ) after conditioning with cognitive performance, highest math class, and selfrated math ability. These average gĉp estimates represent only Bonferroni significant 
relationships; however, each trait pair listed was nominally significant after conditioning with all other EDU and SES phenotypes but not significant in the unconditioned experiment (Table 1).

The EDU/SES phenotype which revealed the most latent causal relationships between mental health outcomes was Townsend deprivation index. Conditioning with this phenotype revealed 7/13 causal relationships, most of which involved bipolar disorder or the volume of the right-ventral diencephalon.

\section{Effects of Mental Health Outcomes on Education and Socioeconomic Status}

We evaluated how shared etiology between mental health outcomes and EDU/SES phenotypes might influence our understanding of the genetics of EDU/SES. After conditioning each EDU and SES phenotype with individual mental health outcomes, all six EDU/SES phenotypes were significantly heritable and maintained high genetic correlation with their unconditioned equivalents (Fig. S6). Attention deficit hyperactivity disorder (ADHD) and tiredness had the most substantial influence on the $h^{2}$ of EDU and SES phenotypes, both of which significantly reduced the $h^{2}$ of EDU/SES phenotypes relative to their original $h^{2}$ estimates. Next, each EDU and SES phenotype was simultaneously conditioned with all genetically correlated mental health outcomes to evaluate how robust EDU and SES phenotypes are to genetic etiology shared with many phenotypes. After conditioning with all mental health outcomes, the EDU/SES phenotypes educational attainment, income, and self-rated math ability maintain significant $\mathrm{h}^{2}$. Conditioned educational attainment (mean $\left.r_{g}=0.999 \pm 0.006\right)$, income (mean $r_{g}=0.988 \pm 0.025$ ), and self-rated math ability (mean $r_{g}=0.987 \pm 0.033$ ) were highly genetically correlated with their unconditioned phenotypes.

Gene set, tissue transcriptomic profile, and cell-type transcriptomic profile enrichments were generally robust to the effects of individual mental health outcomes (Fig S7). After conditioning with $M D D$, the GWAS of self-rated math ability demonstrated a significant decrease in brain cortex tissue transcriptomic profile enrichment (conditioned frontal cortex (BA9) enrichment $=0.106, \mathrm{p}=1.61 \times 10^{-23}$; conditioned cortex enrichment $=0.108, \mathrm{p}=4.48 \times 10^{-23}$; conditioned anterior cingulate cortex $(\mathrm{BA} 24)$ enrichment $\left.=0.106, \mathrm{p}=6.12 \times 10^{-21}\right)$. We then evaluated these enrichment changes in the EDU and SES phenotypes which maintained significant $\mathrm{h}^{2}$ after conditioning with all mental health outcomes (educational attainment, income, and selfrated math ability). Conditioned educational attainment demonstrated changes in enrichment of neurogenesis $\left(\mathrm{p}_{\text {diff }}=1.43 \times 10^{-8}\right)$ and neuron differentiation gene sets $\left(\mathrm{p}_{\text {diff }}=1.61 \times 10^{-7}\right)$ such that they were no longer associated with the GWAS of educational attainment. Conditioned EDU phenotypes educational attainment $\left(9.57 \times 10^{-17}<\mathrm{p}_{\mathrm{diff}}<2.14 \times 10^{-8}\right)$ and self-rated math ability $\left(4.35 \times 10^{-14}<\mathrm{p}_{\text {diff }}<4.21 \times 10^{-12}\right)$ both demonstrated decreased enrichment of cerebellar and cortical tissue transcriptomic profiles. Cell-type transcriptomic profile enrichment changes were generally unique to each phenotype: educational attainment demonstrated decreased enrichment of inhibitory $\left(\operatorname{In} 4, \mathrm{p}_{\text {diff }}=6.38 \times 10^{-14}\right)$ and GABAergic $\left(\mathrm{p}_{\text {diff }}=8.03 \times 10^{-11}\right)$ neurons, self-rated math ability demonstrated decreased enrichment of excitatory $\left(\operatorname{Ex} 1\left(\mathrm{p}_{\mathrm{diff}}=7.37 \times 10^{-11}\right), \operatorname{Ex} 2\left(\mathrm{p}_{\mathrm{diff}}=\right.\right.$ $\left.1.27 \times 10^{-10}\right), \operatorname{Ex} 4\left(\mathrm{p}_{\text {diff }}=9.96 \times 10^{-10}\right), \operatorname{Ex} 5\left(\mathrm{p}_{\text {diff }}=7.27 \times 10^{-10}\right)$, and $\left.\operatorname{Ex} 7\left(\mathrm{p}_{\text {diff }}=1.77 \times 10^{-10}\right)\right)$ neurons, and income demonstrated changes in excitatory $\left(\operatorname{Ex} 1\left(\mathrm{p}_{\text {diff }}=0.004\right), \operatorname{Ex} 4\left(\mathrm{p}_{\text {diff }}=0.005\right), \operatorname{Ex} 5\left(\mathrm{p}_{\text {diff }}\right.\right.$ $=0.001)$, and Ex9 $\left(\mathrm{p}_{\text {diff }}=0.002\right)$ ), inhibitory (In4; $\left.\mathrm{p}_{\text {diff }} 0.001\right)$, and GW26 GABAergic $\left(\mathrm{p}_{\text {diff }}=\right.$ $4.67 \times 10^{-4}$ ) neurons. Consistent with our discoveries regarding cell types underlying mental health outcomes, cell type enrichment changes underlying conditioned EDU and SES phenotypes reflect changes in nervous system development, synaptic signaling, and eye development gene ontologies. 
In a structural equation model assuming a single factor connecting all EDU and SES phenotypes, income was the only trait that did not load independently of all other EDU/SES proxies (loading $=-0.781$; Fig. S8). EFA of EDU and SES phenotypes revealed a two-factor model with major contributions from educational attainment (F1 loading $=0.990$, se $=0.015$ ) and self-rated math ability $(\mathrm{F} 2$ loading $=0.996$, se $=0.046$ ). The correlation between F1 and F2 was 0.426 and was mediated by cognitive performance $(\mathrm{F} 1$ loading $=0.429$, se $=0.018 ; \mathrm{F} 2$ loading $=0.292$, se $=$ 0.027 ) and highest math class (F1 loading $=0.603$, se $=0.024 ; \mathrm{F} 2$ loading $=0.466$, se $=0.029$ ). Notably, the SES phenotype income also did not load onto either factor independently of the other EDU and SES phenotypes in EFA.

After conditioning with all mental health outcomes, we reanalyzed the structural equation models using only those EDU/SES phenotypes with significant $\mathrm{h}^{2}$ (educational attainment, income, and self-rated math ability). Assuming a single factor (as well as EFA and CFA), educational attainment remained a major contributor to the model (common factor loading = 0.986, se $=0.127$ ). In CFA of conditioned phenotypes, the loading value for income significantly increased relative to its original loading value (conditioned common factor loading $=0.118$, se $=$ $0.253, \mathrm{p}_{\text {diff }}=0.018$ ) such that income independently loaded onto the same common factor as educational attainment and self-rated math ability.

\section{Discussion}

EDU and SES are important influences on numerous mental health and disease phenotypes, but it has been difficult to determine the extent to which this is so, and the biological nature of the relationship. How much of the genetic risk for schizophrenia, for example, is caused by reduced educational attainment? Or how much of the risk for schizophrenia reflects a shared biology with the predisposition to educational attainment? These are important questions to answer if we are to understand the biology of both kinds of traits. To get at this question, we conditioned one on the other, and thereby statistically removed its effects, and then asked the question, "how much of the heritable risk for that trait remains?" In most cases, SES/EDU accounted for some of the genetic variance in the mental health or disease phenotype and adjusting for SES/EDU reduced the strength of the association with the heritable risk for that disorder. However, in a few cases (depression, anxiety, neuroticism, PTSD, and subjective well-being) adjusting for SES/EDU either increased or did not change these associations. In the space below, we present a framework for interpreting these complexly of these findings.

\section{Mental Health Outcomes}

The biology underlying psychiatric disorders was most affected by shared genetic etiology with EDU/SES proxies, as evidenced by significant decreases in $\mathrm{h}^{2}$ for all psychiatric disorder except $M D D$, anxiety, and PTSD when conditioned on these traits. Conversely, conditioning the neuroticism and subjective well-being GWAS revealed additional risk loci that were not detected in the original GWAS. Using an independent method, Turley, et al. observed similar information gain (16); however, we demonstrated that this information gain is due to polygenicity rather than population substructure. That is, we believe this demonstrated novel biology, as opposed to the underlying population genetics phenomena. Unlike Turley, et al., we do not report comparable risk locus gain with subjective well-being.

In structural equation models of mental health outcomes, neuroticism and MDD originally loaded onto the same common factor. After conditioning with highest math class, self-rated math ability, and deprivation index, the loadings of neuroticism and MDD separate, suggesting that their 
unique biology may be distinguishable. This is consistent with our observation of ameliorated genetic correlation between these two phenotypes due to conditioning. Hill, et al., described two factors of neuroticism, one of which aligns more closely with anxiety and tension phenotypes and the second of which aligns more closely with worry and vulnerability phenotypes (25). With GenomicSEM, we support these claims: neuroticism loads onto the same common factor as anxiety while MDD aligns with depressive symptoms and loneliness. We demonstrate here that neuroticism and $M D D$ are highly positively genetically correlated in their unconditioned versions. Based on the present results, we hypothesize that conditioning these phenotypes with EDU and SES reveals unique genetic architectures of these phenotypes. We demonstrate that after conditioning with EDU/SES, general neuroticism appears more similar to the Hill, et al. Anxiety/Tension phenotype. Lastly, our GenomicSEM data mirror those genetic correlation results from Hill, et al., adding weight to our observed two-factor model (25).

Cell type transcriptomic profile enrichments underlying the GWAS of mental health outcomes were robust to the effects of EDU and SES phenotypes, but we uncovered new cell-type information for risk tolerance, MDD, schizophrenia, and bipolar disorder. These enrichments highlight unique cell-specific processes underlying these disorders which overlap in phenotypically and genetically similar phenotypes schizophrenia and bipolar disorder: the celltypes discovered in the conditioned schizophrenia GWAS overlap with those in the conditioned bipolar disorder GWAS. These findings recapitulate common therapeutic targets for these disorders. For example, inhibitory and GABAergic neuron transcriptomic profile enrichments were detected in the conditioned MDD GWAS and these are common targets of emerging therapeutic options (e.g., scopolamine, an antidepressant which blocks the M1 receptor of GABAergic interneurons in the medial prefrontal cortex (26); ketamine blocking the activation of somatostatin interneurons in PFC (27)) for MDD and depressive symptoms (26). Detection of these overlapping cell-type transcriptomic profile enrichments supports drug repurposing efforts in psychiatric disorders and related mental health conditions.

Using genome-wide information, we uncovered putatively causal relationships between many mental health outcomes. These analyses revealed well-known relationships between traits (e.g., bipolar disorder, schizophrenia, and $M D D$ ) but also elucidated several novel relationships involving brain imaging phenotypes. In particular we identified the volume of the left subcallosal cortex as a possible mediator of the relationships between several mental health outcomes (e.g., extraversion, subjective well-being, and alcohol dependence) which in turn demonstrate potential causal relationships with mood disorders which are commonly comorbid with alcohol dependence (28). This structural convergence may elucidate common disease mechanisms; however, these commonalities may be confounded by fine-grained nuances of the relationship between brain structure and mental health and disease. The LCV method used to identify these causal relationships does not support multivariable analyses nor does it employ sensitivity tests to detect horizontal pleiotropy (i.e., a SNP is associated with both phenotypes through separate mechanisms) or effect-size outlier SNPs. These observations likely confound our causal inferences and require more robust testing with traditional Mendelian randomization methods suited to accommodate weak genetic instruments (i.e., those SNPs not strongly associated with either phenotypes of interest, typically with association p-values greater than $5 \times 10^{-8}$ ) (29-31).

Certain relationships regarding mental health outcome conditioning that might have been expected, were not observed in our study. Intellectual abilities are genetically correlated with $A S D$ and $A D H D$ and disabilities therein often co-occur with $A S D$ and/or $A D H D$ diagnoses $(32,33)$. According to the Diagnostic and Statistical Manual of Mental Disorders ( $5^{\text {th }}$ Edition, DSM-5), 
medRxiv preprint doi: https://doi.org/10.1101/2020.01.09.20017079; this version posted January 13, 2020. The copyright holder for this preprint (which was not certified by peer review) is the author/funder, who has granted medRxiv a license to display the preprint in perpetuity.

All rights reserved. No reuse allowed without permission.

diagnosis of intellectual disability or global developmental delay must be eliminated as possible explanations of ASD symptoms prior to making a formal ASD diagnosis. We had hypothesized that after conditioning with the effects of EDU phenotypes, these psychiatric disorders might demonstrate notable changes in their underlying biology, but this was not the case. This lack may suggest that ADHD and ASD diagnosis criteria robustly capture elements unique to the disorders rather than those shared with EDU/SES phenotypes. In other words, ascertainment of cases at the extreme ends of spectrum disorders $(34,35)$ reliably capture trait specific biology with minimal phenotype confounding from shared effects with EDU and SES.

\section{Education and Socioeconomic Status}

EDU and SES phenotypes were generally robust to the effects of shared genetic etiology with mental health outcomes. When conditioned with individual mental health outcomes, we detected relatively few changes to the predicted underlying biology of EDU and SES phenotypes. Only when EDU and SES phenotypes were conditioned with several mental health outcomes did we observed changes in $\mathrm{h}^{2}$ and underlying biology. The phenotypes educational attainment, income, and self-rated math ability maintained significant $\mathrm{h}^{2}$ after conditioning with all mental health outcomes. Conversely, the SNP-based observed-scale $\mathrm{h}^{2}$ of cognitive performance, highest math class, and deprivation index disappeared after conditioning with all mental health outcomes. When assessing the relationship between EDU and SES phenotypes, we revealed educational attainment as a driving factor linking EDU and SES phenotypes. Furthermore, we uncovered an independent contribution of income to a common factor with educational attainment and self-rated math ability. Based on recent work of Morris, et al. to uncover why EDU and SES phenotypes are related to one another, these observations point to educational attainment as a mediator of the genetic and phenotypic correlations between EDU and SES.

Tissue and cell-type transcriptomic profile analyses of EDU, SES, and mental health outcome phenotypes highlighted differences in cortical and cerebellar tissue enrichment. Though not significantly decreased in all phenotypes after conditioning, the bidirectional changes in cerebellar and cortical tissue enrichment (i.e., EDU/SES conditioned with mental health outcomes and mental health outcomes conditioned with EDU/SES) highlight the importance of these brain regions and their shared transcriptional regulation in human mental health and disease (36). Furthermore, this observation of cerebellar and cortical tissue changes support the common psychopathology factor (a p-factor) studied extensively in recent mental health and disease research (37). Genetic risk and structural brain imaging changes have been identified underlying this p-factor (37).

\section{Limitations}

Our study has three primary limitations. First, we did not select independent genetic correlates from the mental health outcome phenotypes with which to condition the EDU and SES phenotypes. Due to high genetic correlation between mental health outcomes, this approach may have introduced bias in our reporting of which EDU and SES phenotypes were robust to shared genetic etiology with all mental health outcomes. This potential over-conditioning likely drove our results towards the null (e.g., non-significant $\mathrm{h}^{2}$ ) and therefore, we have not reported gene set, tissue transcriptomic profile enrichment, cell-type transcriptomic profile enrichment, or GenomicSEM loadings for EDU/SES traits where there might have been over-conditioning. For this reason, our results do not imply that, for example, educational attainment is a more powerful or specific EDU phenotype than cognitive ability. Second, it has recently been demonstrated that 
the origin of phenotypic and genetic correlations between EDU and SES phenotypes may be driven by dynastic effects and/or assortative mating acting independently or in concert (6). Dynastic effects describe a condition where offspring inherit phenotype-associated genetic risks and phenotype-associated environmental risks. Assortative mating exists when mate pairs are nonrandomly chosen based on certain attributes. We hypothesize that the dynastic and assortative mating events described between EDU and SES phenotypes (6) may also appear in phenotypic and genetically correlated EDU, SES, and mental health outcome pairs. Future studies will be required to describe how these evolutionary and social pressures influence the correlative and causal relationships uncovered here (e.g., OCD $\rightarrow$ anorexia nervosa after conditioning with the effects of educational attainment, income, and deprivation index). Third, The UK Biobank is considered a generally healthy cohort not enriched for any trait or disorder of interest. To our knowledge, the brain imaging GWAS (performed on a subset of UK Biobank participants) used here were adjusted for variables related to blood pressure, height, weight, and bone mineral composition but are not adjusted for substance-related (recreational or prescribed) or psychiatric variables. The presence of these variables in sufficient quantities among those brain imaging participants could alter brain volumes affecting the results of the genetic analyses conducted.

\section{Conclusions}

By conditioning mental health outcomes for the shared genetic etiology with EDU and SES phenotypes, this study elucidates novel biology and causal relationships between phenotypes. These biological mechanisms, cell-types, tissue-types, and causal trait pairs could not have been detected without adjusting the effects of EDU and SES. This study highlights how the pervasive effects of EDU and SES may mask underlying biology of mental health outcomes in support of multitrait analyses of GWAS to enable trait-specific discoveries.

\section{Materials and Methods}

An overview of all materials, methods, and key findings from this investigation of the genetic overlap between EDU, SES, and mental health outcome phenotypes is shown in a flow diagram in Fig. S1.

\section{Trait Description and Selection}

Four EDU (educational attainment, highest math class, self-rated math ability, and cognitive performance) and two SES phenotypes (household income and Townsend deprivation index) from the Social Science Genetic Association Consortium (SSGAC), UK Biobank (UKB), and $23 \& \mathrm{Me}$ were used in this study to condition mental health outcomes. These unconditioned phenotypes are characterized on the level of heritability, tissue transcriptomic profile enrichment, and cell-type transcriptomic profile enrichment in Fig. S1.

Mental health outcomes from the Psychiatric Genomics Consortium (PGC), SSGAC, Genetics of Personality Consortium (GPC), UKB, and UKB Brain Imaging Genetics (UKB BIG) were selected based on their genetic correlation with EDU and SES phenotypes (Table S1 and Figs. $1 \&$ S2). To focus our analyses, we predetermined that mental health outcomes would be included if (1) they had significant heritability $\left(\mathrm{h}^{2}\right)$, and (2) they were genetically correlated with 2/4 EDU and 2/2 SES phenotypes. It is recommended that each phenotype in a genetic correlation pair have $h^{2}$ z-scores $\geq 4$ (18) but mtCOJO (see below) only requires significant heritability estimates. For this reason, we have relaxed the $\mathrm{h}^{2}$ suggestions for genetic correlation analyses with 
respect to trait inclusion. Genetic correlation estimates should be interpreted in light of this relaxed $\mathrm{h}^{2}$ criteria.

\section{Conditioning}

Conditioning was performed in Genome-wide Complex Trait Analysis (GCTA) using the mtCOJO feature using the 1000 Genomes Project European ancestry linkage disequilibrium reference panel (17). For case-control GWAS summary statistics, odds ratios and corresponding standard error were converted to log-odds and corresponding standard error.

Causal estimates within mtCOJO were calculated using Generalized Summary-data-based Mendelian Randomization (GSMR). In our analyses of mental health outcomes conditioned with the effects of EDU and SES phenotypes, each MR causal inference was performed using genomewide significant SNPs in the exposure (EDU/SES trait). To test how mental health outcomes influence EDU and SES phenotypes, we relaxed this SNP inclusion threshold where necessary (e.g., when UKB BIG phenotypes served as the exposure phenotype) such that at least two SNPs were included in the causal inference.

\section{Heritability and Genetic Correlation}

Observed-scale $\mathrm{h}^{2}$ was calculated for each original and conditioned GWAS using the Linkage Disequilibrium Score Regression (LDSC) method with 1000 Genomes Project European reference population (18).

\section{Gene-set, Tissue Transcriptomic, and Cell-type Transcriptomic Profile Enrichment}

Original and conditioned GWAS were used as standard input for Multi-marker Analysis of GenoMic Annotation (MAGMA v1.06) implemented in FUnctional Mapping and Annotation (FUMA) v1.3.3c with the following parameters: genome-wide significance $\mathrm{p}<5 \times 10^{-8}$, minor allele frequency $\geq 0.01$, and LD blocks merged at $<250 \mathrm{~kb}$ for $\operatorname{LD~} \mathrm{r}^{2} \geq 0.6$ with lead variant $(22,38)$.

SNPs underlying each phenotype of interest were mapped to genes within $10 \mathrm{~kb}$ physical proximity using FUMA (38). Mapped genes were assessed using the gene-set enrichment feature of FUMA, and gene ontology enrichment analysis with ShinyGO (39).

Tissue transcriptomic profile enrichment was performed relative to the GTEx v7 53 tissue types with the default $0 \mathrm{~kb}$ gene window.

Cell-type transcriptomic profile enrichments were performed using eleven human specific transcriptomic profile datasets related to the brain (22): PsychENCODE_Developmental, PsychENCODE_Adult, Allen_Human_LGN_level 1, Allen_Human_MTG_level1, DroNc_Human_Hippocampus, GSE104276_Human_Prefrontal_cortex_all_ages, GSE104276_Human_prefrontal_cortex_per_ages, GSE67835_Human_Cortex, GSE67835_Human_Cortex_woFetal, Linnarson_GSE101601_Human_Temporal_cortex, and Linnarson_GSE76381_Human_Midbrain. Cell-type transcriptomic profiles were assessed in three ways as per the FUMA analysis pipeline. (1) enrichment of cell-type transcriptomic profiles within each selected data set, (2) within data set conditionally independent cell-type transcriptomic profile enrichments, and (3) across data set cell-type transcriptomic profile enrichments.

For analyses within data sets, step-wise conditional significance is evaluated for each cell type in a data set against the p-values for all other cell-types in that same data set. The output from these analyses identify cell types within a data set whose transcriptomic profiles are enriched in a given GWAS independently of the signal from all other cell type transcriptomic profiles in the same data set. 
Using within-data-set conditionally independent cell-types identified above, cross-data-set analysis identifies cell-type transcriptomic profiles enriched in a given GWAS independent of all other cell-types from all chosen data sets. Proportionally significant (PS) and conditionally independent cell-type pairs indicate that enrichment of these cell-types in a given GWAS are driven by independent genetic signals.

For a given pair of cell types, PS of cell type a given cell type $\mathrm{b}\left(\mathrm{PS}_{\mathrm{a}, \mathrm{b}}\right) \geq 0.8$ and $\mathrm{PS}_{\mathrm{b}, \mathrm{a}} \geq$ 0.8 indicates independent genetic signals for cell types a. Interpretation of additional PS thresholds for each cell type in a given pair can be seen in detail (https://fuma.ctglab.nl/tutorial\#celltype) or in Watanabe, et al. (22).

\section{Latent Causal Variables}

LCV is a method for inferring genetic causal relationships between trait pairs using GWAS summary data using effect size estimates or z-scores (24). LCV modeling was implemented in R using the 1000 Genomes Project Phase 3 European reference panel. As recommended, GWAS summary data were filtered to include only SNPs with minor allele frequencies greater than 5\% and the major histocompatibility region was removed due to its complex linkage disequilibrium structure. Note that genetic correlation does not imply that shared genetic risks between traits are causal. The LCV model output distinguishes whether genetic correlations support genetic causation and the degree to which (i.e., the genetic causality proportion; gêp) genetic risk for trait 1 is causal for trait 2. LCV gêp estimates were only interpreted for trait pairs where both traits exhibit LCV-calculated $\mathrm{h}^{2} \mathrm{z}$-scores $\geq 7$.

\section{Statistical Considerations}

Z-tests were used to determine differences in heritability, SNP effects, gene-set enrichments, tissue transcriptomic profile enrichments, cell-type transcriptomic profile enrichments, GenomicSEM loadings, and LCV estimates between conditioned and unconditioned GWAS. 


\section{References}

1. Keyes KM, Platt J, Kaufman AS, McLaughlin KA (2017): Association of Fluid Intelligence and Psychiatric Disorders in a Population-Representative Sample of US Adolescents. JAMA Psychiatry. 74:179-188.

2. McLaughlin KA, Costello EJ, Leblanc W, Sampson NA, Kessler RC (2012): Socioeconomic status and adolescent mental disorders. Am J Public Health. 102:1742-1750.

3. d'Errico A, Ricceri F, Stringhini S, Carmeli C, Kivimaki M, Bartley M, McCrory C, Bochud M, Vollenweider P, Tumino R, Goldberg M, Zins M, Barros H, Giles G, Severi G, Costa $G$, Vineis P (2017): Socioeconomic indicators in epidemiologic research: A practical example from the LIFEPATH study. PLoS One. 12:e0178071.

4. Buniello A, MacArthur JAL, Cerezo M, Harris LW, Hayhurst J, Malangone C, McMahon A, Morales J, Mountjoy E, Sollis E, Suveges D, Vrousgou O, Whetzel PL, Amode R, Guillen JA, Riat HS, Trevanion SJ, Hall P, Junkins H, Flicek P, Burdett T, Hindorff LA, Cunningham F, Parkinson H (2019): The NHGRI-EBI GWAS Catalog of published genome-wide association studies, targeted arrays and summary statistics 2019. Nucleic Acids Res. 47:D1005-D1012.

5. Bulik-Sullivan B, Finucane HK, Anttila V, Gusev A, Day FR, Loh PR, Duncan L, Perry JR, Patterson N, Robinson EB, Daly MJ, Price AL, Neale BM (2015): An atlas of genetic correlations across human diseases and traits. Nat Genet. 47:1236-1241.

6. Morris TT, Davies NM, Hemani G, Smith GD (2019): Why are education, socioeconomic position and intelligence genetically correlated? bioRxiv.630426.

7. Trampush JW, Yang ML, Yu J, Knowles E, Davies G, Liewald DC, Starr JM, Djurovic S, Melle I, Sundet K, Christoforou A, Reinvang I, DeRosse P, Lundervold AJ, Steen VM, Espeseth T, Raikkonen K, Widen E, Palotie A, Eriksson JG, Giegling I, Konte B, Roussos P, Giakoumaki S, Burdick KE, Payton A, Ollier W, Horan M, Chiba-Falek O, Attix DK, Need AC, Cirulli ET, Voineskos AN, Stefanis NC, Avramopoulos D, Hatzimanolis A, Arking DE, Smyrnis N, Bilder RM, Freimer NA, Cannon TD, London E, Poldrack RA, Sabb FW, Congdon E, Conley ED, Scult MA, Dickinson D, Straub RE, Donohoe G, Morris D, Corvin A, Gill M, Hariri AR, Weinberger DR, Pendleton N, Bitsios P, Rujescu D, Lahti J, Le Hellard S, Keller MC, Andreassen OA, Deary IJ, Glahn DC, Malhotra AK, Lencz T (2017): GWAS meta-analysis reveals novel loci and genetic correlates for general cognitive function: a report from the COGENT consortium. Mol Psychiatry. 22:336-345.

8. Marioni RE, Davies G, Hayward C, Liewald D, Kerr SM, Campbell A, Luciano M, Smith BH, Padmanabhan S, Hocking LJ, Hastie ND, Wright AF, Porteous DJ, Visscher PM, Deary IJ (2014): Molecular genetic contributions to socioeconomic status and intelligence. Intelligence. 44:26-32.

9. Hill WD, Hagenaars SP, Marioni RE, Harris SE, Liewald DCM, Davies G, Okbay A, McIntosh AM, Gale CR, Deary IJ (2016): Molecular Genetic Contributions to Social Deprivation and Household Income in UK Biobank. Curr Biol. 26:3083-3089.

10. Anttila V, Bulik-Sullivan B, Finucane HK, Walters RK, Bras J, Duncan L, Escott-Price V, Falcone GJ, Gormley P, Malik R, Patsopoulos NA, Ripke S, Wei Z, Yu D, Lee PH, Turley P, Grenier-Boley B, Chouraki V, Kamatani Y, Berr C, Letenneur L, Hannequin D, Amouyel P, Boland A, Deleuze JF, Duron E, Vardarajan BN, Reitz C, Goate AM, Huentelman MJ, Kamboh MI, Larson EB, Rogaeva E, St George-Hyslop P, Hakonarson H, Kukull WA, Farrer LA, Barnes LL, Beach TG, Demirci FY, Head E, Hulette CM, Jicha GA, Kauwe JSK, Kaye JA, Leverenz JB, Levey AI, Lieberman AP, Pankratz VS, Poon WW, Quinn JF, Saykin AJ, Schneider LS, Smith AG, Sonnen JA, Stern RA, Van Deerlin VM, Van Eldik LJ, Harold D, Russo G, Rubinsztein DC, 
Bayer A, Tsolaki M, Proitsi P, Fox NC, Hampel H, Owen MJ, Mead S, Passmore P, Morgan K, Nothen MM, Rossor M, Lupton MK, Hoffmann P, Kornhuber J, Lawlor B, McQuillin A, AlChalabi A, Bis JC, Ruiz A, Boada M, Seshadri S, Beiser A, Rice K, van der Lee SJ, De Jager PL, Geschwind DH, Riemenschneider M, Riedel-Heller S, Rotter JI, Ransmayr G, Hyman BT, Cruchaga C, Alegret M, Winsvold B, Palta P, Farh KH, Cuenca-Leon E, Furlotte N, Kurth T, Ligthart L, Terwindt GM, Freilinger T, Ran C, Gordon SD, Borck G, Adams HHH, Lehtimaki T, Wedenoja J, Buring JE, Schurks M, Hrafnsdottir M, Hottenga JJ, Penninx B, Artto V, Kaunisto M, Vepsalainen S, Martin NG, Montgomery GW, Kurki MI, Hamalainen E, Huang H, Huang J, Sandor C, Webber C, Muller-Myhsok B, Schreiber S, Salomaa V, Loehrer E, Gobel H, Macaya A, Pozo-Rosich P, Hansen T, Werge T, Kaprio J, Metspalu A, Kubisch C, Ferrari MD, Belin AC, van den Maagdenberg A, Zwart JA, Boomsma D, Eriksson N, Olesen J, Chasman DI, Nyholt DR, Avbersek A, Baum L, Berkovic S, Bradfield J, Buono R, Catarino CB, Cossette P, De Jonghe P, Depondt C, Dlugos D, Ferraro TN, French J, Hjalgrim H, Jamnadas-Khoda J, Kalviainen R, Kunz WS, Lerche H, Leu C, Lindhout D, Lo W, Lowenstein D, McCormack M, Moller RS, Molloy A, Ng PW, Oliver K, Privitera M, Radtke R, Ruppert AK, Sander T, Schachter S, Schankin C, Scheffer I, Schoch S, Sisodiya SM, Smith P, Sperling M, Striano P, Surges R, Thomas GN, Visscher F, Whelan CD, Zara F, Heinzen EL, Marson A, Becker F, Stroink H, Zimprich F, Gasser T, Gibbs R, Heutink P, Martinez M, Morris HR, Sharma M, Ryten M, Mok KY, Pulit S, Bevan S, Holliday E, Attia J, Battey T, Boncoraglio G, Thijs V, Chen WM, Mitchell B, Rothwell P, Sharma P, Sudlow C, Vicente A, Markus H, Kourkoulis C, Pera J, Raffeld M, Silliman S, Boraska Perica V, Thornton LM, Huckins LM, William Rayner N, Lewis CM, Gratacos M, Rybakowski F, KeskiRahkonen A, Raevuori A, Hudson JI, Reichborn-Kjennerud T, Monteleone P, Karwautz A, Mannik K, Baker JH, O'Toole JK, Trace SE, Davis OSP, Helder SG, Ehrlich S, HerpertzDahlmann B, Danner UN, van Elburg AA, Clementi M, Forzan M, Docampo E, Lissowska J, Hauser J, Tortorella A, Maj M, Gonidakis F, Tziouvas K, Papezova H, Yilmaz Z, Wagner G, Cohen-Woods S, Herms S, Julia A, Rabionet R, Dick DM, Ripatti S, Andreassen OA, Espeseth T, Lundervold AJ, Steen VM, Pinto D, Scherer SW, Aschauer H, Schosser A, Alfredsson L, Padyukov L, Halmi KA, Mitchell J, Strober M, Bergen AW, Kaye W, Szatkiewicz JP, Cormand B, Ramos-Quiroga JA, Sanchez-Mora C, Ribases M, Casas M, Hervas A, Arranz MJ, Haavik J, Zayats T, Johansson S, Williams N, Dempfle A, Rothenberger A, Kuntsi J, Oades RD, Banaschewski T, Franke B, Buitelaar JK, Arias Vasquez A, Doyle AE, Reif A, Lesch KP, Freitag C, Rivero O, Palmason H, Romanos M, Langley K, Rietschel M, Witt SH, Dalsgaard S, Borglum AD, Waldman I, Wilmot B, Molly N, Bau CHD, Crosbie J, Schachar R, Loo SK, McGough JJ, Grevet EH, Medland SE, Robinson E, Weiss LA, Bacchelli E, Bailey A, Bal V, Battaglia A, Betancur C, Bolton P, Cantor R, Celestino-Soper P, Dawson G, De Rubeis S, Duque F, Green A, Klauck SM, Leboyer M, Levitt P, Maestrini E, Mane S, De-Luca DM, Parr J, Regan R, Reichenberg A, Sandin S, Vorstman J, Wassink T, Wijsman E, Cook E, Santangelo S, Delorme R, Roge B, Magalhaes T, Arking D, Schulze TG, Thompson RC, Strohmaier J, Matthews K, Melle I, Morris D, Blackwood D, McIntosh A, Bergen SE, Schalling M, Jamain S, Maaser A, Fischer SB, Reinbold CS, Fullerton JM, Guzman-Parra J, Mayoral F, Schofield PR, Cichon S, Muhleisen TW, Degenhardt F, Schumacher J, Bauer M, Mitchell PB, Gershon ES, Rice J, Potash JB, Zandi PP, Craddock N, Ferrier IN, Alda M, Rouleau GA, Turecki G, Ophoff R, Pato C, Anjorin A, Stahl E, Leber M, Czerski PM, Cruceanu C, Jones IR, Posthuma D, Andlauer TFM, Forstner AJ, Streit F, Baune BT, Air T, Sinnamon G, Wray NR, MacIntyre DJ, Porteous D, Homuth G, Rivera M, Grove J, Middeldorp CM, Hickie I, Pergadia M, Mehta D, Smit JH, Jansen R, de Geus E, Dunn E, Li QS, Nauck M, Schoevers RA, Beekman AT, Knowles JA, Viktorin A, Arnold P, Barr CL, 
Bedoya-Berrio G, Bienvenu OJ, Brentani H, Burton C, Camarena B, Cappi C, Cath D, Cavallini M, Cusi D, Darrow S, Denys D, Derks EM, Dietrich A, Fernandez T, Figee M, Freimer N, Gerber G, Grados M, Greenberg E, Hanna GL, Hartmann A, Hirschtritt ME, Hoekstra PJ, Huang A, Huyser C, Illmann C, Jenike M, Kuperman S, Leventhal B, Lochner C, Lyon GJ, Macciardi F, Madruga-Garrido M, Malaty IA, Maras A, McGrath L, Miguel EC, Mir P, Nestadt G, Nicolini H, Okun MS, Pakstis A, Paschou P, Piacentini J, Pittenger C, Plessen K, Ramensky V, Ramos EM, Reus V, Richter MA, Riddle MA, Robertson MM, Roessner V, Rosario M, Samuels JF, Sandor P, Stein DJ, Tsetsos F, Van Nieuwerburgh F, Weatherall S, Wendland JR, Wolanczyk T, Worbe Y, Zai G, Goes FS, McLaughlin N, Nestadt PS, Grabe HJ, Depienne C, Konkashbaev A, Lanzagorta N, Valencia-Duarte A, Bramon E, Buccola N, Cahn W, Cairns M, Chong SA, Cohen D, CrespoFacorro B, Crowley J, Davidson M, DeLisi L, Dinan T, Donohoe G, Drapeau E, Duan J, Haan L, Hougaard D, Karachanak-Yankova S, Khrunin A, Klovins J, Kucinskas V, Lee Chee Keong J, Limborska S, Loughland C, Lonnqvist J, Maher B, Mattheisen M, McDonald C, Murphy KC, Nenadic I, van Os J, Pantelis C, Pato M, Petryshen T, Quested D, Roussos P, Sanders AR, Schall U, Schwab SG, Sim K, So HC, Stogmann E, Subramaniam M, Toncheva D, Waddington J, Walters J, Weiser M, Cheng W, Cloninger R, Curtis D, Gejman PV, Henskens F, Mattingsdal M, Oh SY, Scott R, Webb B, Breen G, Churchhouse C, Bulik CM, Daly M, Dichgans M, Faraone SV, Guerreiro R, Holmans P, Kendler KS, Koeleman B, Mathews CA, Price A, Scharf J, Sklar P, Williams J, Wood NW, Cotsapas C, Palotie A, Smoller JW, Sullivan P, Rosand J, Corvin A, Neale BM, Schott JM, Anney R, Elia J, Grigoroiu-Serbanescu M, Edenberg HJ, Murray R (2018): Analysis of shared heritability in common disorders of the brain. Science. 360.

11. Zhang Y, Qi G, Park JH, Chatterjee N (2018): Estimation of complex effect-size distributions using summary-level statistics from genome-wide association studies across 32 complex traits. Nat Genet. 50:1318-1326.

12. Choi SW, O'Reilly PF (2019): PRSice-2: Polygenic Risk Score software for biobank-scale data. Gigascience. 8.

13. Avinun R (2019): Educational Attainment Polygenic Score is Associated with Depressive Symptoms via Socioeconomic Status: A Gene-Environment-Trait Correlation. bioRxiv.727552.

14. Krapohl E, Plomin R (2016): Genetic link between family socioeconomic status and children's educational achievement estimated from genome-wide SNPs. Mol Psychiatry. 21:437443.

15. Richards AL, Pardinas AF, Frizzati A, Tansey KE, Lynham AJ, Holmans P, Legge SE, Savage JE, Agartz I, Andreassen OA, Blokland GAM, Corvin A, Cosgrove D, Degenhardt F, Djurovic S, Espeseth T, Ferraro L, Gayer-Anderson C, Giegling I, van Haren NE, Hartmann AM, Hubert JJ, Jonsson EG, Konte B, Lennertz L, Olde Loohuis LM, Melle I, Morgan C, Morris DW, Murray RM, Nyman H, Ophoff RA, van Os J, Petryshen TL, Quattrone D, Rietschel M, Rujescu D, Rutten BPF, Streit F, Strohmaier J, Sullivan PF, Sundet K, Wagner M, Escott-Price V, Owen MJ, Donohoe G, O'Donovan MC, Walters JTR (2019): The Relationship Between Polygenic Risk Scores and Cognition in Schizophrenia. Schizophr Bull.

16. Turley P, Walters RK, Maghzian O, Okbay A, Lee JJ, Fontana MA, Nguyen-Viet TA, Wedow R, Zacher M, Furlotte NA, Magnusson P, Oskarsson S, Johannesson M, Visscher PM, Laibson D, Cesarini D, Neale BM, Benjamin DJ (2018): Multi-trait analysis of genome-wide association summary statistics using MTAG. Nat Genet. 50:229-237.

17. Zhu Z, Zheng Z, Zhang F, Wu Y, Trzaskowski M, Maier R, Robinson MR, McGrath JJ, Visscher PM, Wray NR, Yang J (2018): Causal associations between risk factors and common diseases inferred from GWAS summary data. Nat Commun. 9:224. 
18. Bulik-Sullivan BK, Loh PR, Finucane HK, Ripke S, Yang J, Patterson N, Daly MJ, Price AL, Neale BM (2015): LD Score regression distinguishes confounding from polygenicity in genome-wide association studies. Nat Genet. 47:291-295.

19. Eroglu C, Allen NJ, Susman MW, O'Rourke NA, Park CY, Ozkan E, Chakraborty C, Mulinyawe SB, Annis DS, Huberman AD, Green EM, Lawler J, Dolmetsch R, Garcia KC, Smith SJ, Luo ZD, Rosenthal A, Mosher DF, Barres BA (2009): Gabapentin receptor alpha2delta-1 is a neuronal thrombospondin receptor responsible for excitatory CNS synaptogenesis. Cell. 139:380392.

20. Vergult S, Dheedene A, Meurs A, Faes F, Isidor B, Janssens S, Gautier A, Le Caignec C, Menten B (2015): Genomic aberrations of the CACNA2D1 gene in three patients with epilepsy and intellectual disability. Eur J Hum Genet. 23:628-632.

21. Crayton JW, Meltzer HY (1979): Degeneration and regeneration of motor neurons in psychotic patients. Biol Psychiatry. 14:803-819.

22. Watanabe K, Umicevic Mirkov M, de Leeuw CA, van den Heuvel MP, Posthuma D (2019): Genetic mapping of cell type specificity for complex traits. Nat Commun. 10:3222.

23. Lake BB, Chen S, Sos BC, Fan J, Kaeser GE, Yung YC, Duong TE, Gao D, Chun J, Kharchenko PV, Zhang K (2018): Integrative single-cell analysis of transcriptional and epigenetic states in the human adult brain. Nat Biotechnol. 36:70-80.

24. O'Connor LJ, Price AL (2018): Distinguishing genetic correlation from causation across 52 diseases and complex traits. Nat Genet.

25. Hill WD, Weiss A, Liewald DC, Davies G, Porteous DJ, Hayward C, McIntosh AM, Gale CR, Deary IJ (2019): Genetic contributions to two special factors of neuroticism are associated with affluence, higher intelligence, better health, and longer life. Mol Psychiatry.

26. Duman RS, Sanacora G, Krystal JH (2019): Altered Connectivity in Depression: GABA and Glutamate Neurotransmitter Deficits and Reversal by Novel Treatments. Neuron. 102:75-90.

27. Gerhard DM, Pothula S, Liu RJ, Wu M, Li XY, Girgenti MJ, Taylor SR, Duman CH, Delpire E, Picciotto M, Wohleb ES, Duman RS (2019): GABA interneurons are the cellular trigger for ketamine's rapid antidepressant actions. J Clin Invest.

28. Andersen AM, Pietrzak RH, Kranzler HR, Ma L, Zhou H, Liu X, Kramer J, Kuperman S, Edenberg HJ, Nurnberger JI, Jr., Rice JP, Tischfield JA, Goate A, Foroud TM, Meyers JL, Porjesz B, Dick DM, Hesselbrock V, Boerwinkle E, Southwick SM, Krystal JH, Weissman MM, Levinson DF, Potash JB, Gelernter J, Han S (2017): Polygenic Scores for Major Depressive Disorder and Risk of Alcohol Dependence. JAMA Psychiatry. 74:1153-1160.

29. Burgess S, Bowden J, Fall T, Ingelsson E, Thompson SG (2017): Sensitivity Analyses for Robust Causal Inference from Mendelian Randomization Analyses with Multiple Genetic Variants. Epidemiology. 28:30-42.

30. Hartwig FP, Davey Smith G, Bowden J (2017): Robust inference in summary data Mendelian randomization via the zero modal pleiotropy assumption. Int J Epidemiol. 46:19851998.

31. Zhao Q, Wang J, Hemani G, Bowden J, Small DS (2018): Statistical inference in twosample summary data Mendelian randomization using robust adjusted profile score. arXiv.

32. Clarke TK, Lupton MK, Fernandez-Pujals AM, Starr J, Davies G, Cox S, Pattie A, Liewald DC, Hall LS, MacIntyre DJ, Smith BH, Hocking LJ, Padmanabhan S, Thomson PA, Hayward C, Hansell NK, Montgomery GW, Medland SE, Martin NG, Wright MJ, Porteous DJ, Deary IJ, McIntosh AM (2016): Common polygenic risk for autism spectrum disorder (ASD) is associated with cognitive ability in the general population. Mol Psychiatry. 21:419-425. 
medRxiv preprint doi: https://doi.org/10.1101/2020.01.09.20017079; this version posted January 13, 2020. The copyright holder for this preprint (which was not certified by peer review) is the author/funder, who has granted medRxiv a license to display the preprint in perpetuity.

All rights reserved. No reuse allowed without permission.

33. Klein M, Walters RK, Demontis D, Stein JL, Hibar DP, Adams HH, Bralten J, Roth Mota N, Schachar R, Sonuga-Barke E, Mattheisen M, Neale BM, Thompson PM, Medland SE, Borglum AD, Faraone SV, Arias-Vasquez A, Franke B (2019): Genetic Markers of ADHD-Related Variations in Intracranial Volume. Am J Psychiatry. 176:228-238.

34. Abu-Akel A, Allison C, Baron-Cohen S, Heinke D (2019): The distribution of autistic traits across the autism spectrum: evidence for discontinuous dimensional subpopulations underlying the autism continuum. Mol Autism. 10:24.

35. Larsson H, Anckarsater H, Rastam M, Chang Z, Lichtenstein P (2012): Childhood attention-deficit hyperactivity disorder as an extreme of a continuous trait: a quantitative genetic study of 8,500 twin pairs. J Child Psychol Psychiatry. 53:73-80.

36. Gandal MJ, Haney JR, Parikshak NN, Leppa V, Ramaswami G, Hartl C, Schork AJ, Appadurai V, Buil A, Werge TM, Liu C, White KP, Horvath S, Geschwind DH (2018): Shared molecular neuropathology across major psychiatric disorders parallels polygenic overlap. Science. 359:693-697.

37. Romer AL, Knodt AR, Houts R, Brigidi BD, Moffitt TE, Caspi A, Hariri AR (2018): Structural alterations within cerebellar circuitry are associated with general liability for common mental disorders. Mol Psychiatry. 23:1084-1090.

38. Watanabe K, Taskesen E, van Bochoven A, Posthuma D (2017): Functional mapping and annotation of genetic associations with FUMA. Nat Commun. 8:1826.

39. Ge SX, Jung D (2018): ShinyGO: a graphical enrichment tool for ani-mals and plants. bioRxiv.315150. 
medRxiv preprint doi: https://doi.org/10.1101/2020.01.09.20017079; this version posted January 13, 2020. The copyright holder for this preprint

(which was not certified by peer review) is the author/funder, who has granted medRxiv a license to display the preprint in perpetuity.

All rights reserved. No reuse allowed without permission.

\section{Acknowledgements}

General: We would like to thank the research participants and employees of 23andMe Inc for making this work possible.

Funding: This study was supported by the Simons Foundation Autism Research Initiative (SFARI Explorer Award: 534858 (RP)), the American Foundation for Suicide Prevention (YIG-1-109-16 (RP)), the National Institutes of Health (R21 DC018098 (RP), R21 DA047527 (RP), and R01 MH117646 (TL)), and the National Center for PTSD of the U.S. Department of Veterans Affairs.

Author contributions: FW and RP conceived the analyses; FW performed analyses; FW, GP, and RP interpreted the data; TL, JK, and JG provided critical analytic and data interpretation feedback; FW drafted the manuscript; FW, GP, TL, JK, JG, and RP edited and approved final manuscript.

Competing interests: The authors have no competing interests.

Data and materials availability: All data and analysis materials used in the study are publicly available for download. 


\section{Figure and Figure Legends}

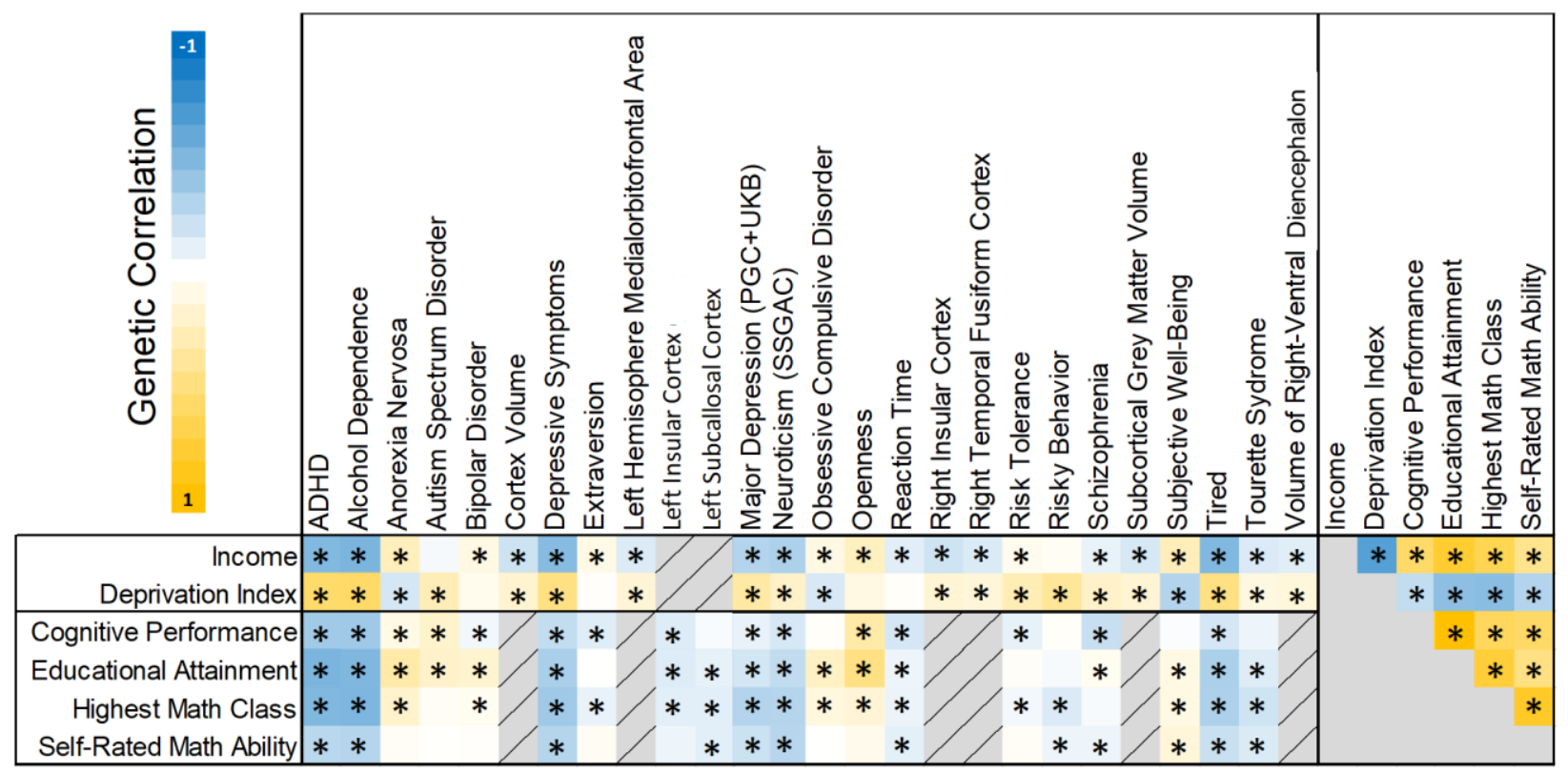

Fig. 1. Trait inclusion genetic correlations. Genetic correlation between mental health outcomes, education phenotypes, and socioeconomic status phenotypes. Genetic correlations labeled with an asterisk were at least nominally significant. 

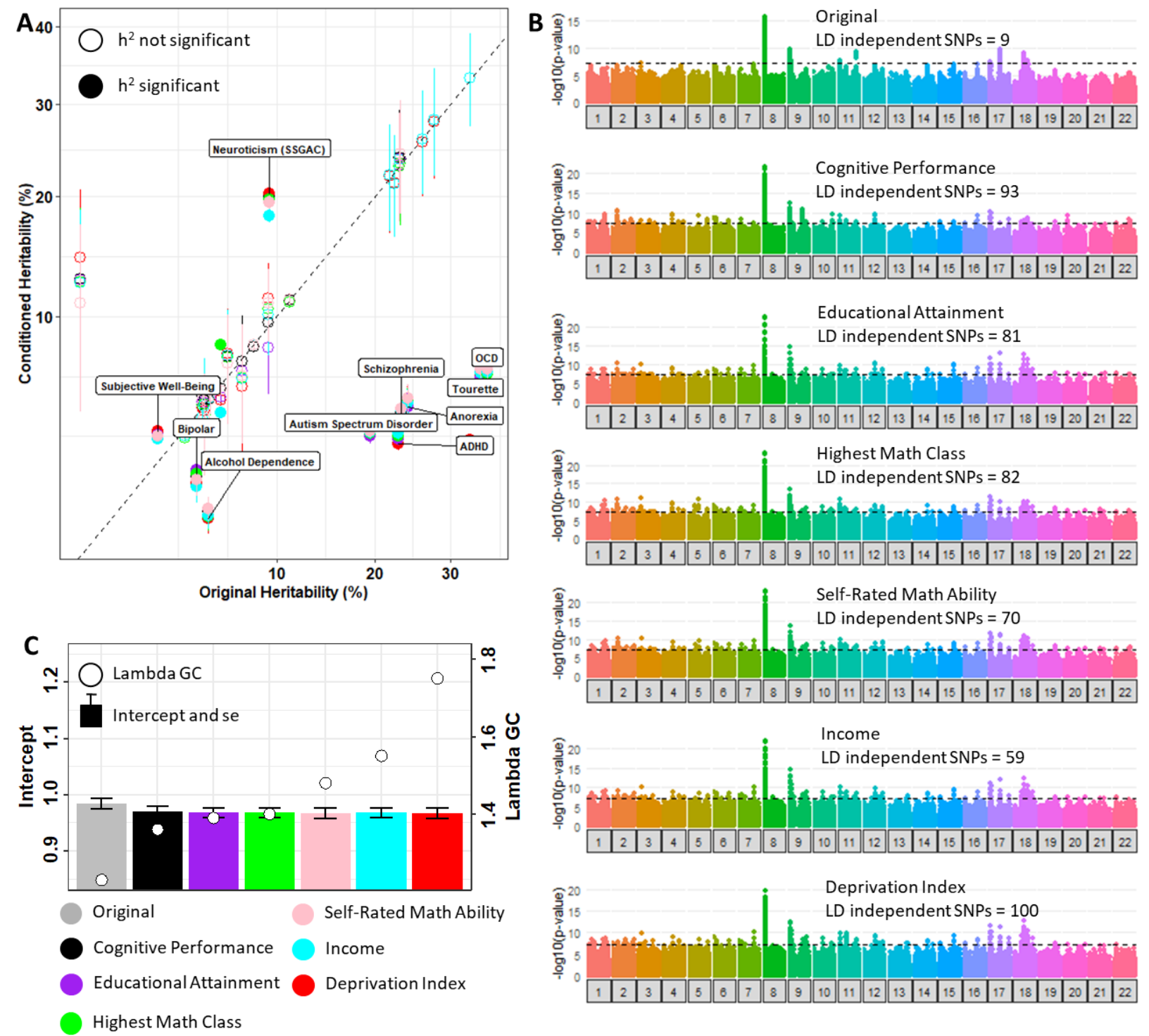

Fig. 2. Heritability $\left(h^{2}\right)$ changes and risk locus discovery. (A) Observed-scale $h^{2}$ changes of mental health outcomes after conditioning with education and socioeconomic status phenotypes. (B) Manhattan plots for neuroticism (SSGAC) before and after conditioning with education and socioeconomic status phenotypes. (C) Evidence that neuroticism (SSGAC) locus discovery is due to increased detection of polygenicity rather than exacerbated effects of population substructure. 


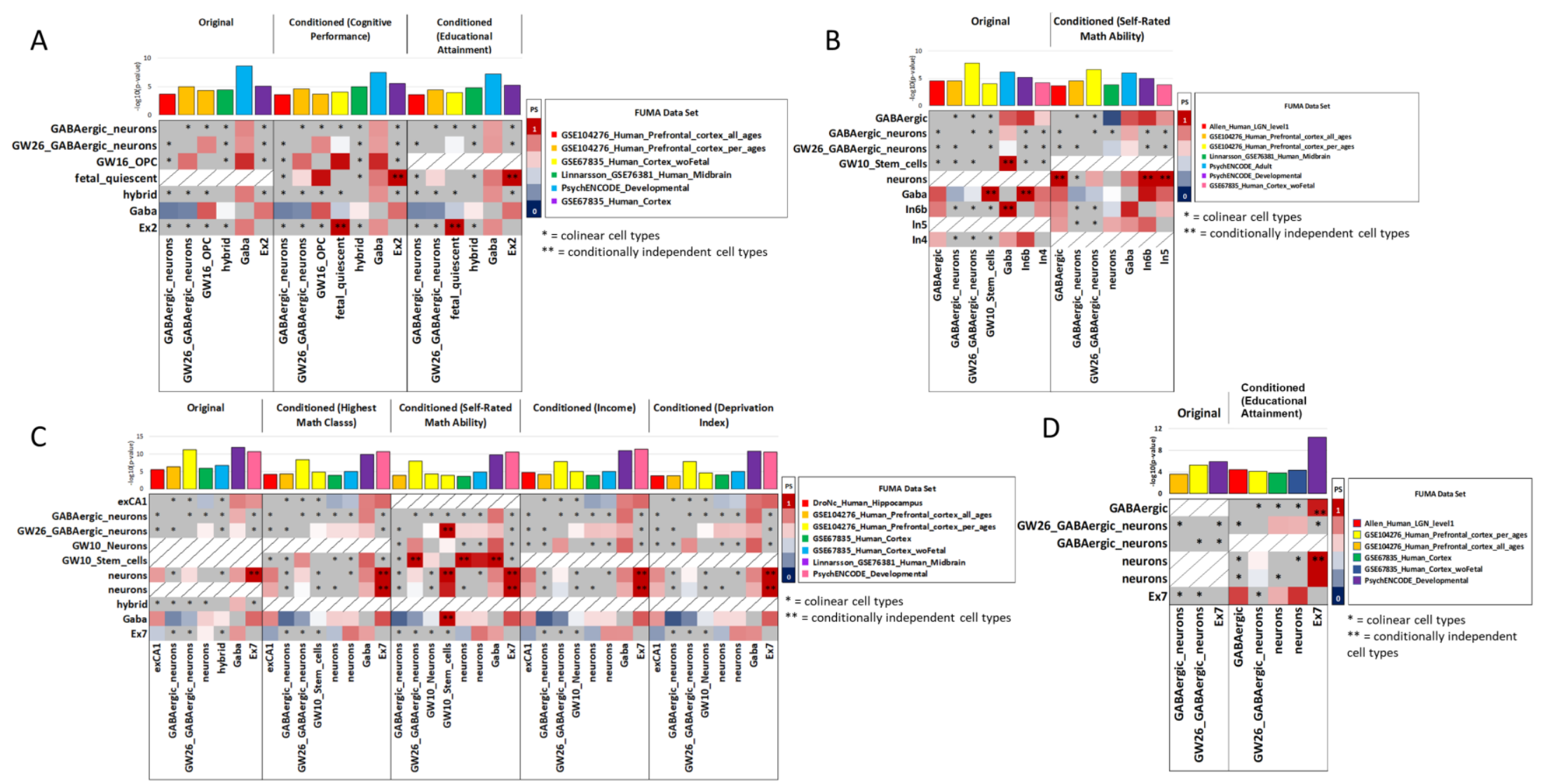

Fig. 3. Cell-type transcriptomic profile enrichments underlying mental health outcomes. Cross-data-set proportionally significant (PS) and conditionally independent (i.e., genetic signatures of cell-type pairs are distinguishable) cell-type transcriptomic profile enrichments underlying unconditioned and conditioned GWAS for (A) risky behavior, (B) major depression, (C) schizophrenia, and (D) bipolar disorder. The human cell-type data sets from FUMA are labeled individually for each panel using different colors; cell types in the $\mathrm{x}$ and $\mathrm{y}$ directions are conditionally independent signals from within-data-set analysis performed in FUMA (cell-type enrichment step 2 (22)). Genetic signals from colinear cell types labeled with a single asterisk could not be differentiated from one another in FUMA. 


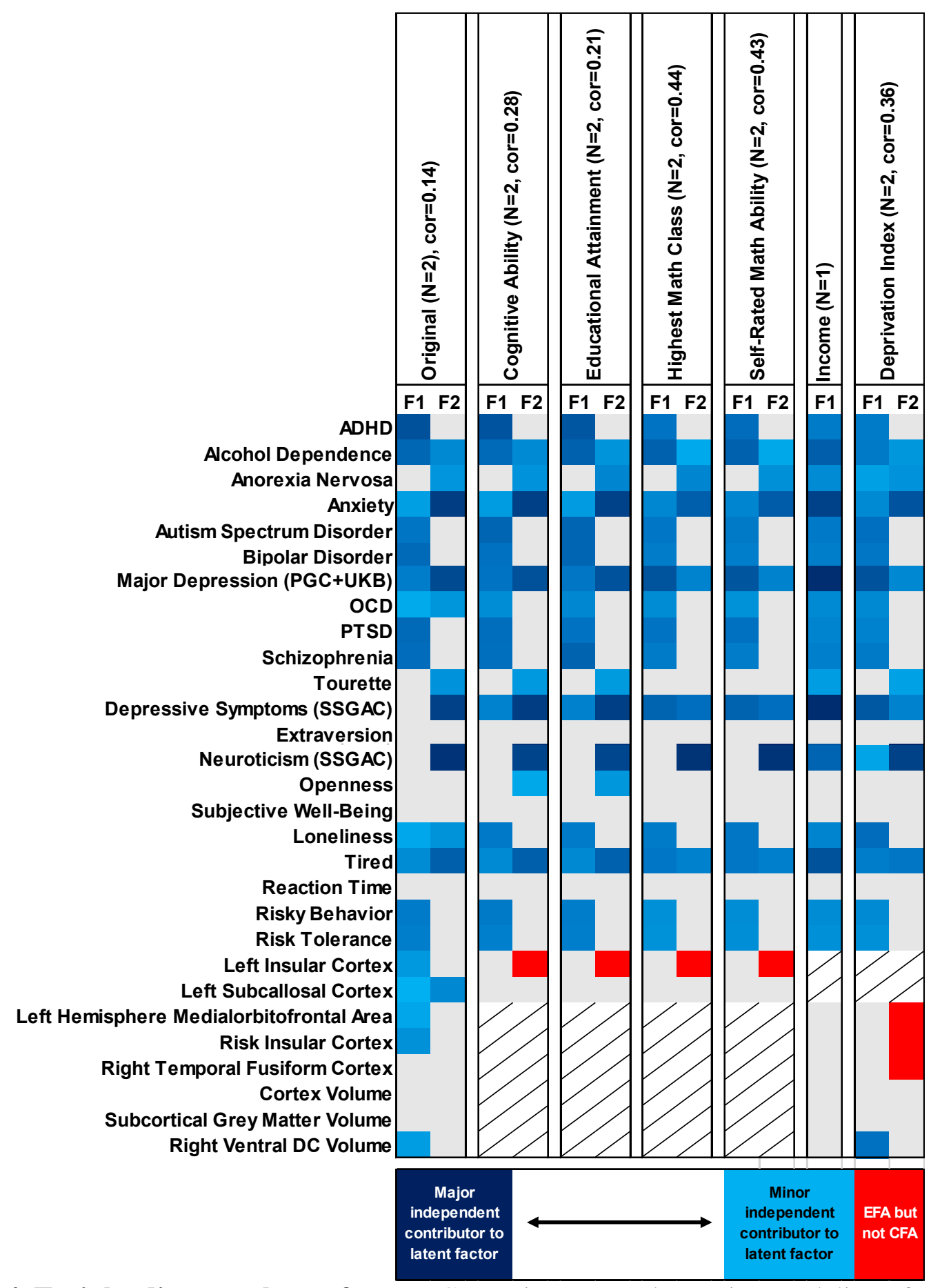

Fig. 4. Trait loading onto latent factors. Genomic structural equation modeling of mental health outcomes before and after conditioning with education and socioeconomic status phenotypes. Each column shows the confirmatory factor analysis (CFA) loading value (blue shading indicating that a trait is a major contributor to the latent factor and blue tinting indicating that a trait is a minor independent contributor to the latent factor) for each mental health outcome (in the y direction) into one of two factors (F1 and F2) from exploratory factor analysis (EFA). Grey boxes indicate that a given trait was not predicted to load onto a given factor column. Red boxes indicate that the trait was predicted by EFA to load onto a factor but did not independently load during CFA. 


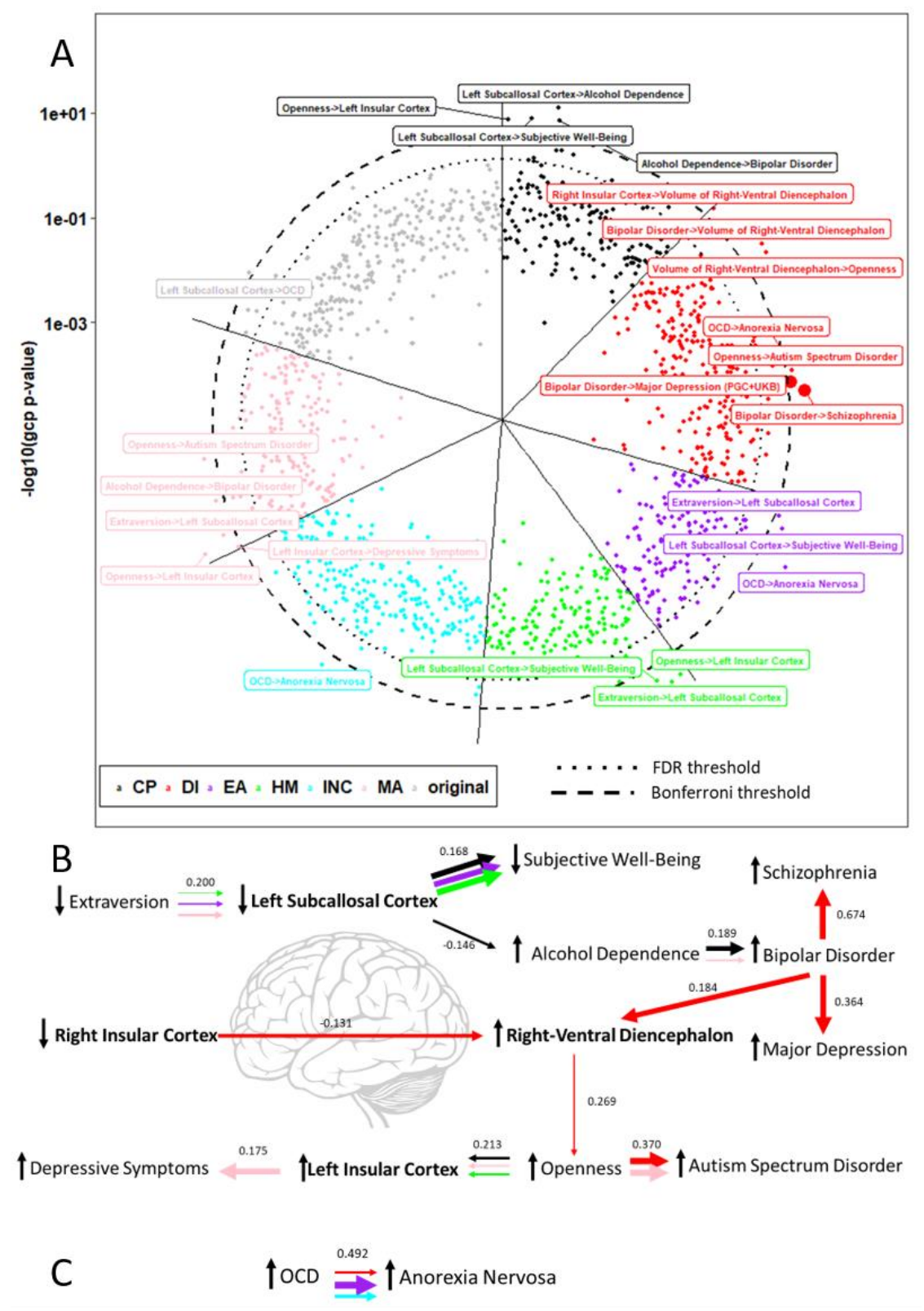

Fig 5. Causal relationships masked by education and socioeconomic status effects. Latent Causal Variable (LCV) results detecting causal relationships between the genetic risk for two mental health outcomes. (A) Colors are used to indicate original trait pair and conditioned trait pair LCV results. LCV genetic causality proportions surviving multiple testing correction are labeled. Large data points indicate significantly different LCV genetic causality proportions relative to the unconditioned estimate. (B) Summary of the causal relationship (derived from A) network originating from brain imaging phenotypes (bolded text). (C) Causal relationships with no evidence of brain imaging phenotype connection in the current study (derived from A). In $\mathbf{B}$ and $\mathbf{C}$, horizontal arrow thickness indicates the size of the estimated causal relationship between the two traits on either end of the arrow while the direction of each arrow indicates the direction of causal effect; the color of each arrow indicates the education or socioeconomic status phenotype used to condition each trait of a trait pair; mean genetic correlations from LCV are included above each set of horizontal arrows. 
medRxiv preprint doi: https://doi.org/10.1101/2020.01.09.20017079; this version posted January 13, 2020. The copyright holder for this preprint

(which was not certified by peer review) is the author/funder, who has granted medRxiv a license to display the preprint in perpetuity.

All rights reserved. No reuse allowed without permission.

Table 1. Causal inferences detected after multiple testing correction. Significant causal relationships detected between mental health outcomes using latent causal variable analyses. For each significant causal estimate, all conditioned causal estimates between that phenotype pair are provided, highlighting at least nominally significant causal inferences after conditioning with education and socioeconomic status phenotypes that could not be detected in the original unconditioned trait pair.

Submitted as a separate file. 
medRxiv preprint doi: https://doi.org/10.1101/2020.01.09.20017079; this version posted January 13, 2020. The copyright holder for this preprint (which was not certified by peer review) is the author/funder, who has granted medRxiv a license to display the preprint in perpetuity.

\section{Supplementary Materials}

\section{Supplementary Results}

\section{Trait Inclusion}

Left and right insular cortex brain imaging phenotypes have been treated as differentially genetically correlated with EDU and SES, respectively. (1) Though not included in the conditioning experiments involving EDU phenotypes, the right insular cortex was nominally significantly genetically correlated with educational attainment $\left(r_{g}=-0.118, p=0.044\right)$ and (2) though not included in the conditioning experiments involving SES phenotypes, the left insular cortex was nominally significantly genetically correlated with income $\left(r_{g}=0.183, p=0.004\right)$.

\section{Gene-set Enrichment Differences}

Using MAGMA (38), we tested for differences between the gene set enrichments of original and conditioned mental health outcome GWASs. Gene set enrichments for each mental health outcomes were robust to the effects of conditioning with EDU and SES phenotypes. No significant changes were observed in gene set enrichments underlying the GWAS of mental health outcomes. 
medRxiv preprint doi: https://doi.org/10.1101/2020.01.09.20017079; this version posted January 13, 2020. The copyright holder for this preprint (which was not certified by peer review) is the author/funder, who has granted medRxiv a license to display the preprint in perpetuity.

All rights reserved. No reuse allowed without permission.

A)

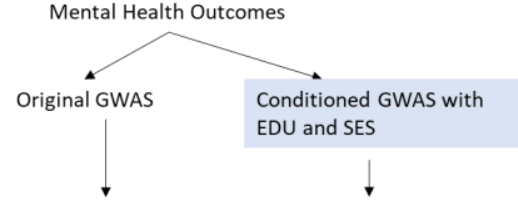

B)

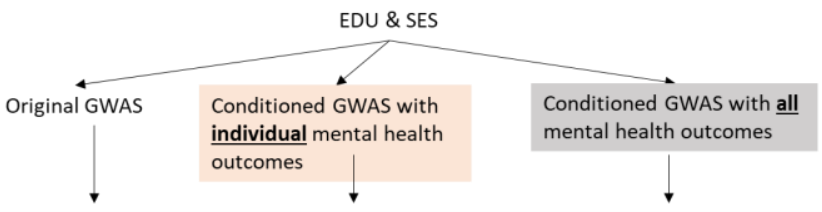

) - $10 \mathrm{~S}^{2}$ calculation $\rightarrow z$-tests to compare original versus conditioned GWAS - Genomic risk loci characterized for traits with $h^{2}$ increase, assess polygenicity versus population substructure

\begin{tabular}{|c|c|c|}
\hline $\begin{array}{l}\text { Neuroticism exhibited increased } \mathrm{h} 2 \text { after conditioning } \\
\text { Neuroticism } \mathrm{h}^{2} \text { increase due to uncovered polygenicity, no } \\
\text { population substructure } \\
\mathrm{H}^{2} \text { of psychiatric disorders ubiquitously decreased after conditioning }\end{array}$ & $\begin{array}{l}\text { No change in } \mathrm{h}^{2} \\
\quad \text { No change in risk locus discovery }\end{array}$ & $\begin{array}{l}\text { Conditioned cognitive performance, deprivation index, and highest } \\
\text { math class } \mathrm{h}^{2} \text { were no different from zero } \\
\text { Risk loci persisted for educational attainment, self-rated math ability, } \\
\text { and income, despite reduced } \mathrm{h}^{2}\end{array}$ \\
\hline \multicolumn{3}{|c|}{$\begin{array}{l}\text { Gene Set Enrichment Changes } \\
\text { from MAGMA } \rightarrow \text {-test to compare original enrichment to conditioned enrichment }\end{array}$} \\
\hline No change in gene set enrichment & - No change in gene set enrichment & $\begin{array}{l}\text { - Enrichment of neurogenesis and neuron differentiation gene sets of } \\
\text { educational attainment significantly reduced }\end{array}$ \\
\hline
\end{tabular}

Tissue Transcriptomic Profile Enrichment Changes - Enrichment of GTEx v7 53 tissue transcriptomic profiles from MAGMA $\rightarrow z$-tests to compare original enrichment to conditioned enrichments

\begin{tabular}{l|l} 
No change in tissue transcriptomic profile enrichment & . Enrichment of frontal cortex (BA9), anterior cingulate cortex (BA24),
\end{tabular} and cortex brain tissues of self-rated math ability significantly Enrichment of cerebellum and cerebellar hemisphere tissues of income significant decreased after conditioning with left hemisphere medialorbitofrontal area of the brain

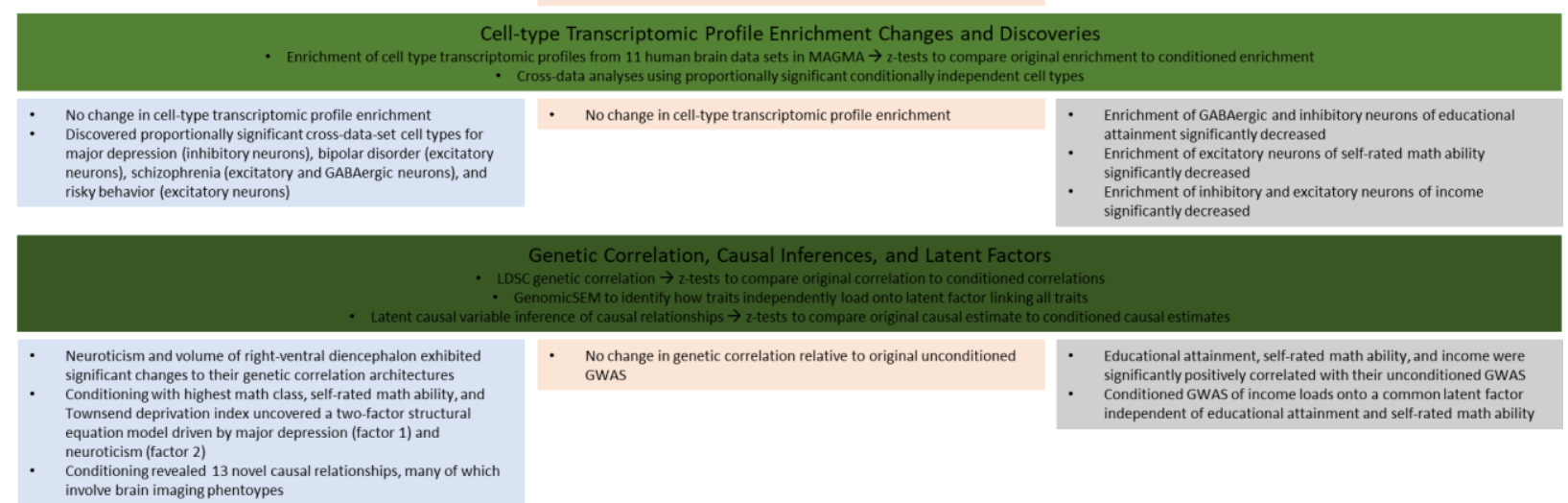

Fig. S1. Analytic pipeline. The overall analysis plans and methods used (green boxes) and key results from each phase of analysis for (A; blue boxes) mental health outcomes conditioned with education and socioeconomic status phenotypes and (B) education and socioeconomic status phenotypes conditioned with individual mental health outcomes (orange boxes) and all mental health outcomes (grey boxes). 
medRxiv preprint doi: https://doi.org/10.1101/2020.01.09.20017079; this version posted January 13, 2020. The copyright holder for this preprint (which was not certified by peer review) is the author/funder, who has granted medRxiv a license to display the preprint in perpetuity.

All rights reserved. No reuse allowed without permission.

\begin{tabular}{|c|c|c|c|c|c|c|c|c|c|c|c|c|}
\hline Trait & Source & $\begin{array}{l}\text { Sample } \\
\text { Size }\end{array}$ & $\begin{array}{l}\mathrm{h}^{2} \mathrm{z}- \\
\text { score }\end{array}$ & Tissue & beta & se & $\mathrm{p}$ & Within Dataset Independent Cell Types & $\begin{array}{l}\text { Cross } \\
\text { Dataset }\end{array}$ & beta & se & $\mathrm{p}$ \\
\hline $\begin{array}{l}\text { Self-Rated } \\
\text { Math } \\
\text { Ability }\end{array}$ & 23\&Me & 564,698 & 36.95 & 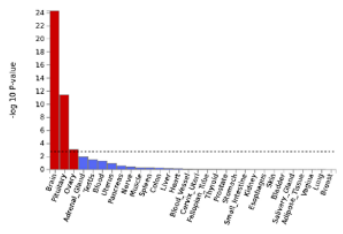 & 0.114 & 0.011 & $4.68 \mathrm{E}-25$ & 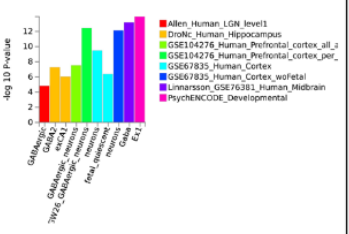 & $\begin{array}{c}\text { Ex1 } \\
\text { Fetal } \\
\text { quiescent }\end{array}$ & \begin{tabular}{l|}
0.082 \\
0.067
\end{tabular} & $\begin{array}{l}0.010 \\
0.014\end{array}$ & $\begin{array}{l}1.14 \mathrm{E}-14 \\
4.23 \mathrm{E}-07\end{array}$ \\
\hline $\begin{array}{l}\text { Highest } \\
\text { Math Class }\end{array}$ & 23\&Me & 430,445 & 36.56 & 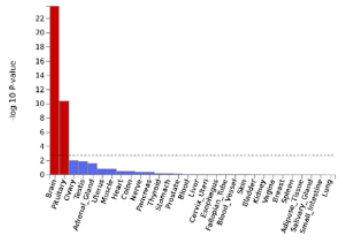 & 0.107 & 0.011 & $1.78 \mathrm{E}-24$ & 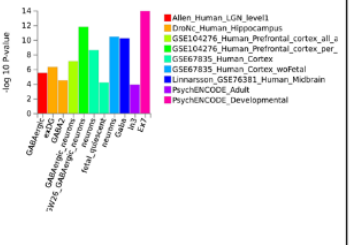 & \begin{tabular}{|c|} 
Ex7 \\
Fetal \\
quiescent \\
Neuron
\end{tabular} & $\begin{array}{l}0.076 \\
0.050 \\
0.071\end{array}$ & $\begin{array}{l}0.010 \\
0.012 \\
0.013\end{array}$ & \begin{tabular}{|l|}
$3.49 \mathrm{E}-13$ \\
$5.62 \mathrm{E}-05$ \\
$2.16 \mathrm{E}-09$
\end{tabular} \\
\hline $\begin{array}{c}\text { Educational } \\
\text { Attainment }\end{array}$ & $\begin{array}{l}\text { Social } \\
\text { Science } \\
\text { Genetic } \\
\text { Association } \\
\text { Consortium }\end{array}$ & 766,345 & 41 & 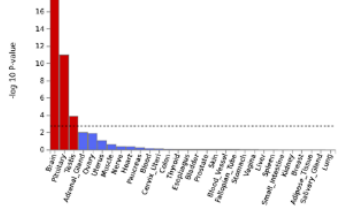 & 0.101 & 0.011 & $4.05 E-19$ & 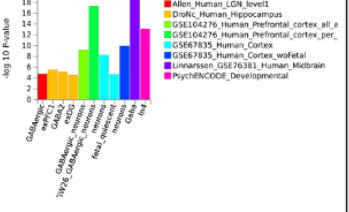 & $\begin{array}{c}\text { Ln4 } \\
\text { Fetal } \\
\text { quiescent } \\
\text { Neuron }\end{array}$ & $\begin{array}{l}0.088 \\
0.056 \\
0.075\end{array}$ & $\begin{array}{l}0.012 \\
0.013 \\
0.018\end{array}$ & $\begin{array}{l}7.94 \mathrm{E}-14 \\
1.97 \mathrm{E}-05 \\
5.43 \mathrm{E}-09\end{array}$ \\
\hline $\begin{array}{l}\text { Cognitive } \\
\text { Perf. }\end{array}$ & $\begin{array}{l}\text { Social } \\
\text { Science } \\
\text { Genetic } \\
\text { Association } \\
\text { Consortium }\end{array}$ & 257,828 & 31 & 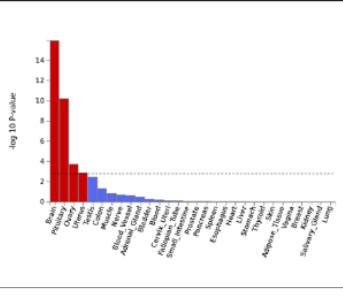 & 0.082 & 0.010 & $1.09 \mathrm{E}-16$ & 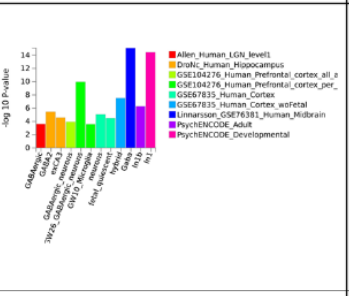 & $\begin{array}{c}\text { Microglia } \\
\text { Fetal } \\
\text { quiescent } \\
\text { Neurons } \\
\text { Ln1b } \\
\text { Ln1 } \\
\text { ExCA3 }\end{array}$ & $\begin{array}{l}0.018 \\
0.050 \\
0.050 \\
0.923 \\
0.092 \\
1.10\end{array} \mid$ & $\begin{array}{l}0.005 \\
0.012 \\
0.016 \\
0.189 \\
0.012 \\
0.273 \\
\end{array}$ & $\begin{array}{l}2.70 \mathrm{E}-04 \\
3.41 \mathrm{E}-05 \\
8.61 \mathrm{E}-06 \\
4.98 \mathrm{E}-07 \\
3.42 \mathrm{E}-15 \\
2.63 \mathrm{E}-05\end{array}$ \\
\hline Income & UK Biobank & 360,763 & 25.31 & 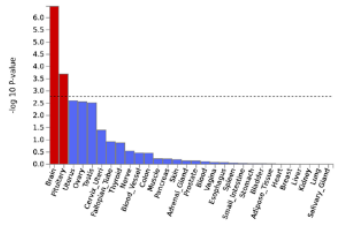 & 0.043 & 0.009 & $3.43 \mathrm{E}-07$ & 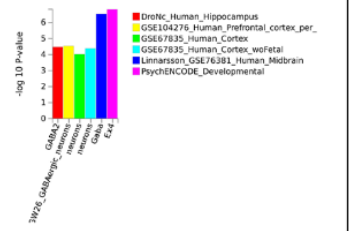 & $\begin{array}{c}\text { Ex4 } \\
\text { Neuron } \\
\text { Neuron }\end{array}$ & $\begin{array}{l}0.044 \\
0.037 \\
0.038\end{array}$ & $\begin{array}{l}0.009 \\
0.010 \\
0.010\end{array}$ & $\begin{array}{l}1.49 \mathrm{E}-07 \\
9.58 \mathrm{E}-05 \\
4.05 \mathrm{E}-05\end{array}$ \\
\hline $\begin{array}{l}\text { Townsend } \\
\text { Deprivation } \\
\text { Index }\end{array}$ & UK Biobank & 311,028 & 18.5 & 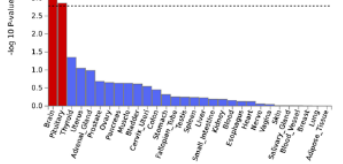 & 0.030 & 0.008 & $4.11 \mathrm{E}-05$ & NA & NA & NA & NA & NA \\
\hline
\end{tabular}

Fig. S2. Description of education and socioeconomic status phenotypes. Summary level data for education and socioeconomic status phenotypes on the level of phenotype heritability, tissue transcriptomic profile enrichment, and cell-type transcriptomic profile enrichment. 

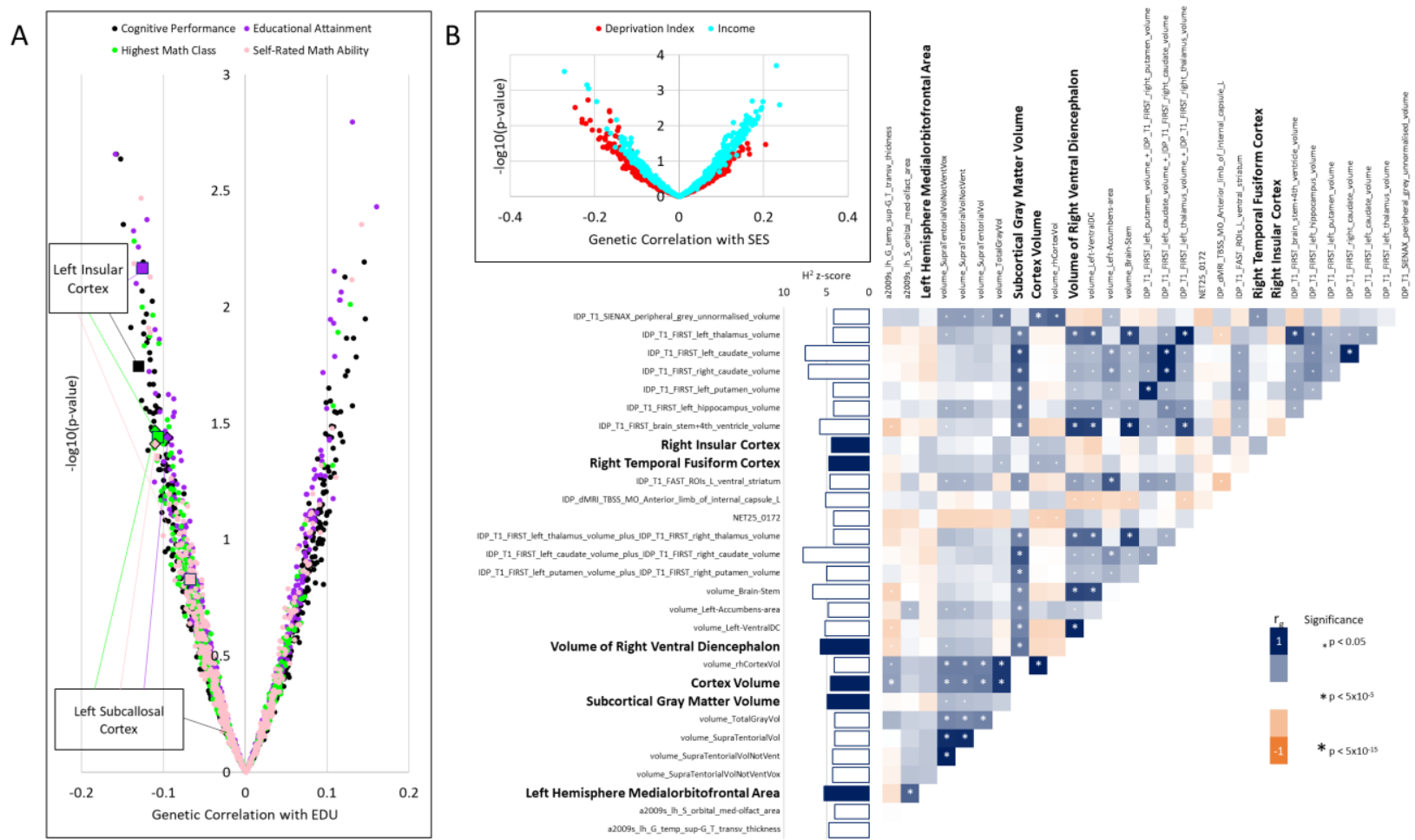

Fig. S3. Selection of brain imaging phenotypes. (A) Brain imaging phenotypes genetically correlated with education phenotypes: educational attainment, highest math class, self-rated math ability, and cognitive performance. (B) Brain imaging phenotypes nominally genetically correlated with socioeconomic status phenotypes: household income and Townsend deprivation index. Heatmap shows genetic correlations between socioeconomic status genetic correlates and their respective per-trait heritability z-scores. Six bolded brain imaging phenotypes were selected for conditioning experiments due to their heritability estimate relative to strongly genetically correlated traits. 


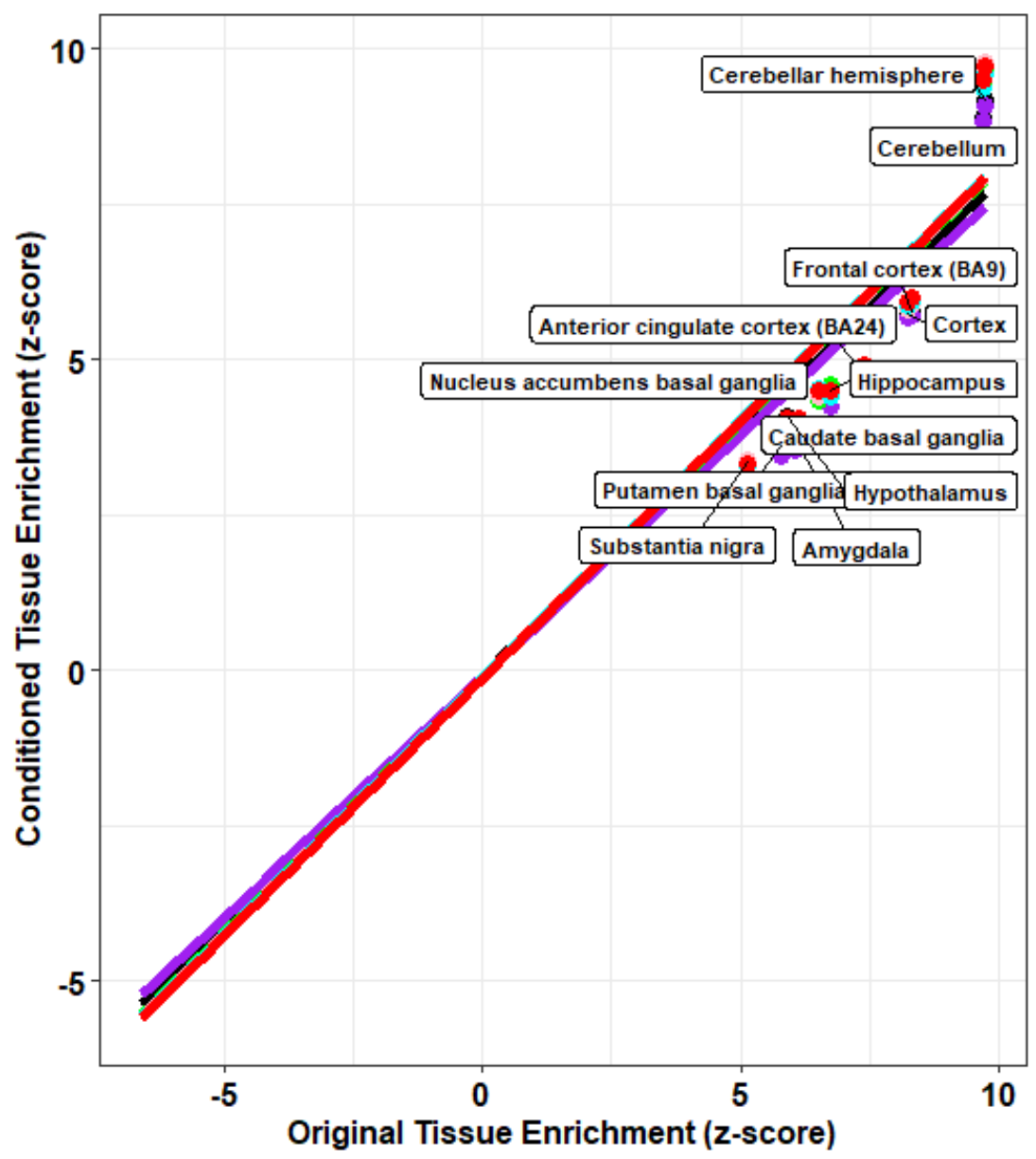

Fig S4. Tissue changes in schizophrenia GWAS. Robust linear regression between original and conditioned tissue transcriptomic profile enrichments in the schizophrenia GWAS. The schizophrenia GWAS was conditioned with education and socioeconomic status phenotypes: educational attainment (purple regression line), highest math class (green regression line), selfrated math ability (pink regression line), cognitive performance (black regression line), income (cyan regression line), and Townsend deprivation index (red regression line). Tissues are labeled if conditioning with education and socioeconomic status significantly reduced their enrichment in the schizophrenia GWAS. 

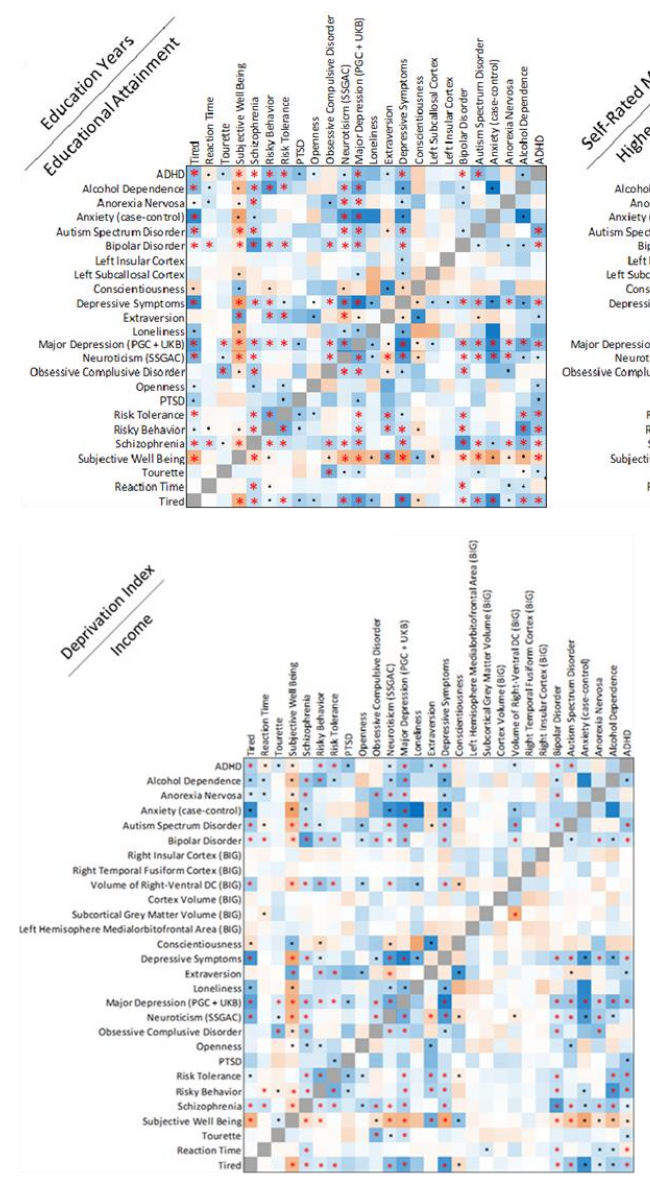
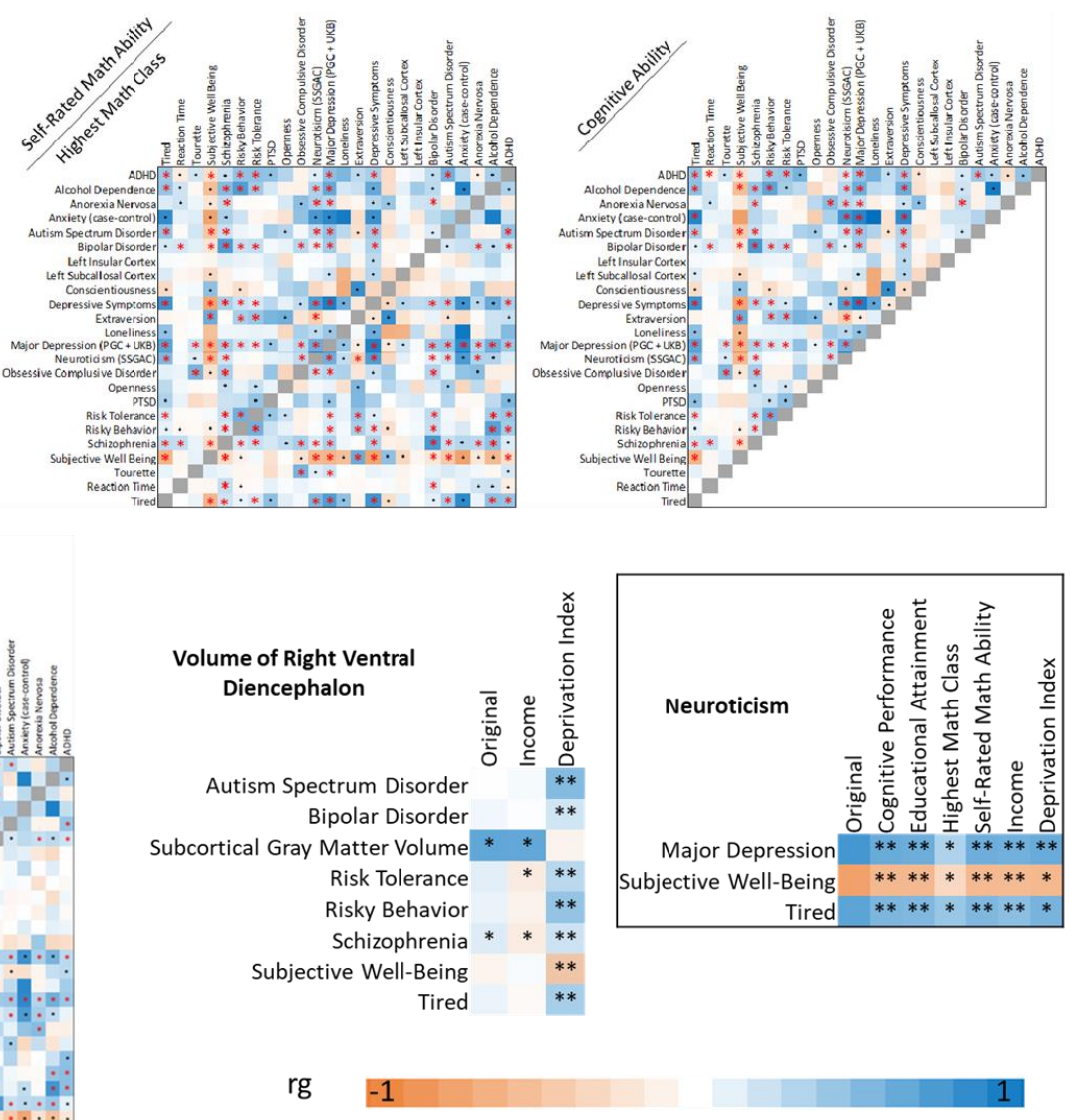

Fig. S5. Mental health outcome genetic correlations. Genetic correlation architecture of all mental health outcomes shown as heatmaps. Red asterisks indicate genetic correlations surviving Bonferroni correction, single black asterisks indicate at least nominally significant genetic correlations, and double black asterisks indicate genetic correlations that are significantly different than their unconditioned equivalent. 
medRxiv preprint doi: https://doi.org/10.1101/2020.01.09.20017079; this version posted January 13, 2020. The copyright holder for this preprint (which was not certified by peer review) is the author/funder, who has granted medRxiv a license to display the preprint in perpetuity.

All rights reserved. No reuse allowed without permission.

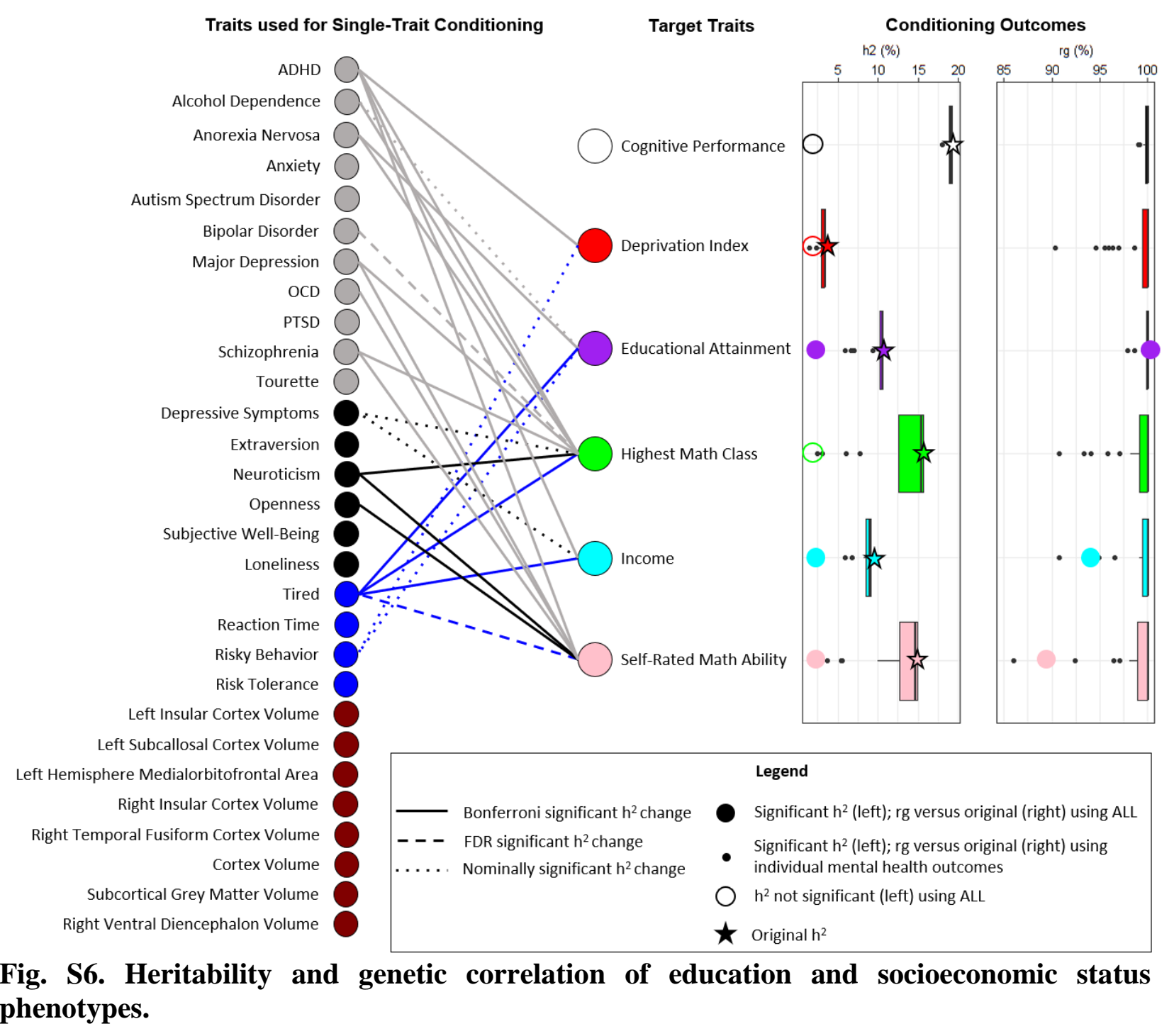



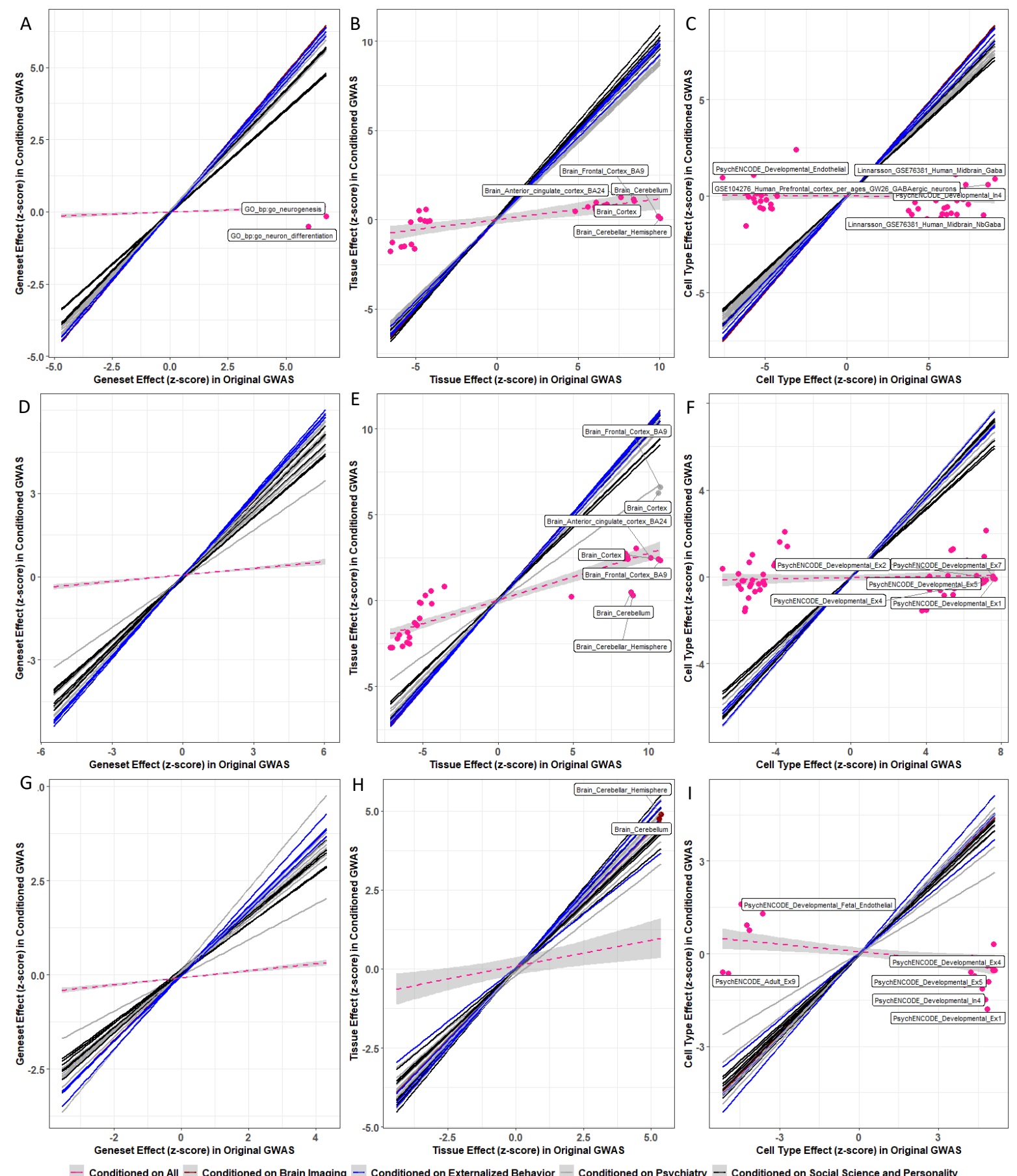

Fig S7. Gene set, tissue transcriptomic profile, and cell-type transcriptomic profile enrichment changes. Each panel shows the robust linear regression between original gene set (A, $\mathbf{D}, \mathbf{G})$, tissue transcriptomic profiles $(\mathbf{B}, \mathbf{E}, \mathbf{H})$, and cell-type transcriptomic profiles $(\mathbf{C}, \mathbf{F}, \mathbf{I})$ and conditioned enrichments for educational attainment (A-C), self-rated math ability (D-F), and income (G-I). For visual clarity, standard errors around each linear regression are shown for traits resulting in a significant change of enrichment and for each trait conditioned on all mental health outcomes (pink dashed regression lines). Data points indicate annotations with significant different enrichments after conditioning; the top five differentially enriched annotations are labeled. 

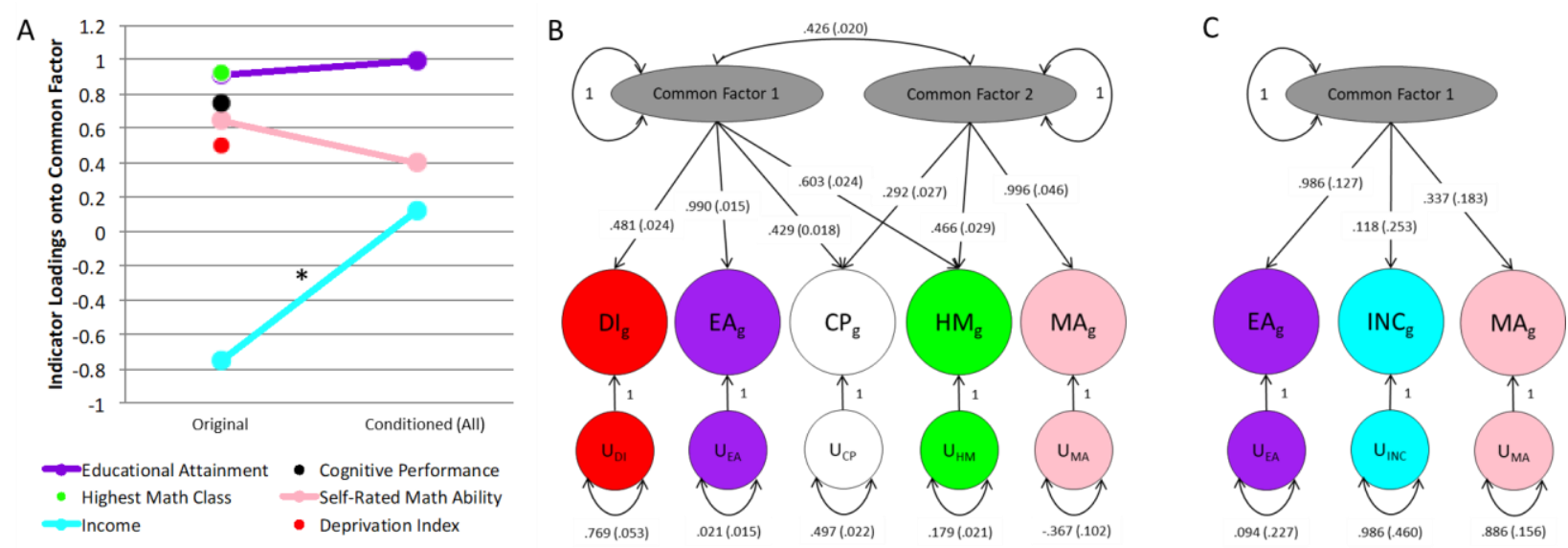

Fig. S8. Summary of Genomic Structural Equation Modeling (GenomicSEM). (A) SEM of education (EDU) and socioeconomic status (SES) phenotypes assuming all phenotypes load onto a single common factor. The same model with significantly heritably conditioned phenotypes is shown. Asterisks indicate significant changes in loading value. (B) Confirmatory factor analysis of unconditioned EDU and SES proxies. (C) Confirmatory factor analysis of EDU and SES proxies conditioned with all mental health outcomes. 


\section{Table S1. Description of mental health outcomes assessed.}

\begin{tabular}{|c|c|c|c|}
\hline Trait & Source & Sample Size & $\mathbf{H}^{2} \%$ (z-score) \\
\hline Autism Spectrum Disorder & PGC & 18,382 cases and 27,969 controls & $19.41(11.55)$ \\
\hline Attention Deficit Hyperactivity Disorder & PGC & 20,183 cases and 35,191 controls & $22.81(15.41)$ \\
\hline Schizophrenia & PGC & 36,989 cases and 113,075 controls & $23.22(25.24)$ \\
\hline Post-traumatic Stress Disorder & PGC & 2,424 cases and 7,113 controls & $4.86(2.26)$ \\
\hline Anorexia Nervosa & PGC & 3,495 cases and 10,982 controls & $24.03(6.29)$ \\
\hline Alcohol Dependence & PGC & 8,485 cases and 20,272 controls & $5.08(4.38)$ \\
\hline Major Depressive Disorder & $\mathrm{PGC}+\mathrm{UKB}$ & 246,363 cases and 561,190 controls & $3.75(25)$ \\
\hline Bipolar Disorder & PGC & 20,352 cases and 31,358 controls & $4.32(12)$ \\
\hline Tourette Syndrome & PGC & 4,819 cases and 9,488 controls & $35.62(8.32)$ \\
\hline Obsessive Compulsive Disorder & PGC & 2,688 cases and 7,037 controls & $34.56(7.2)$ \\
\hline Anxiety (Case-Control) & ANGST & 5,761 cases and 11,765 controls & $7.26(2.49)$ \\
\hline Subjective Well-Being & SSGAC & 298,420 & $2.5(12.5)$ \\
\hline Neuroticism & SSGAC & 170,911 & $9.41(14.26)$ \\
\hline Depressive Symptoms & SSGAC & 161,460 & $4.72(12.76)$ \\
\hline Risk Tolerance & SSGAC & 466,571 & $5.13(23.32)$ \\
\hline Risky Behavior & SSGAC & 315,894 & $11.09(26.4)$ \\
\hline Openness & GPC & 17,375 & $9.27(4.14)$ \\
\hline Conscientiousness & GPC & 17,375 & $6.32(2.47)$ \\
\hline Extraversion & GPC & 63,991 & $5.19(6.33)$ \\
\hline Loneliness & Gao, et al. 2017 & 2,853 cases and 4,583 controls & $0.3(2.14)$ \\
\hline Reaction Time & CCACE/UKB & 330,069 & $8.13(27.1)$ \\
\hline Tiredness & CCACE/UKB & 108,976 & $5.84(21.63)$ \\
\hline Left Insular Cortex & BIG & 8,428 & $23.13(4.18)$ \\
\hline Right Insular Cortex & BIG & 8,428 & $21.76(4.20)$ \\
\hline Left Subcallosal Cortex & BIG & 8,428 & $22.96(4.34)$ \\
\hline Right Temporal Fusiform Cortex & BIG & 8,428 & $26.03(4.51)$ \\
\hline Volume of Right-Ventral Diencephalon & BIG & 8,428 & $32.83(5.41)$ \\
\hline Cortex Volume & BIG & 8,428 & $22.36(4.47)$ \\
\hline Subcortical Grey Matter Volume & BIG & 8,428 & $27.58(4.57)$ \\
\hline Left Hemisphere Medialorbitofrontal Area & BIG & 8,428 & $23.11(4.83)$ \\
\hline
\end{tabular}

